\title{
A participação popular no licenciamento ambiental no Estado da Paraíba, Nordeste do Brasil
}

\section{Vital José Pessoa Madruga Filho* e Reinaldo Farias Paiva de Lucena}

Universidade Federal da Paraíba. Centro de Ciências Exatas e da Natureza. Programa de Pós-Graduação em Desenvolvimento e Meio Ambiente (PRODEMA). Campus I. João Pessoa-PB (CEP 58051-900). *E-mail: vitalpessoa@bol.com.br.

Resumo. 0 estudo trata do licenciamento ambiental, que é um instrumento de controle e proteção do meio ambiente, servindo de meio para o estabelecimento de empreitadas que importem degradação ambiental ou que necessite da utilização de recursos naturais, impondo medidas capazes de arrefecer os impactos gerados pela atividade degradadora. Para atender esse propósito, estabeleceu-se como objetivo geral analisar a participação da população nos processos de licenciamento ambiental na Paraíba, Nordeste do Brasil, confrontando-a com a metodologia adotada pela Superintendência de Administração do Meio Ambiente da Paraíba (SUDEMA-PB). Quanto à metodologia, a pesquisa é de cunho qualitativo, e serviu-se de fontes bibliográficas e documentais disponíveis, a fim de demonstrar a forma com que as audiências públicas são conduzidas e medir a eficácia da participação popular no procedimento. Acerca dos resultados, observou-se que o convite formulado à população não é capaz de acudir a um número razoável de cidadãos, além do que foi possível observar que fatores de cunho social acabam dificultando o acesso e a participação popular nas audiências públicas de licenciamento ambiental.

Palavras-chave: Política Nacional do Meio Ambiente; Licenciamento ambiental; Participação popular.

Abstract. The popular participation in environmental
licensing in the State of Paraíba, Northeast Brazil. This study
deals with environmental licensing, which is an instrument to
control and protect the environment, being used for the
establishment of enterprises that implicate environmental
degradation or that require the use of natural resources,
imposing measures able to mitigate the impacts generated by the
degrading activity. For this purpose, the general objective of this
study was to evaluate the population's participation in
environmental licensing processes in Paraíba State, Northeast
Brazil, confronting it with the methodology adopted by the
Superintendence of Environment Management of Paraíba
(SUDEMA-PB). This is a qualitative research based on available
bibliographical and documentary sources and aims at ISSN 2359-1412/RBGAS-2019-0027/2019/6/14/3/623
Recebido

14/04/2019

Aceito

$15 / 11 / 2019$

Disponível on line

$15 / 11 / 2019$

Publicado

$31 / 12 / 2019$

Acesso aberto

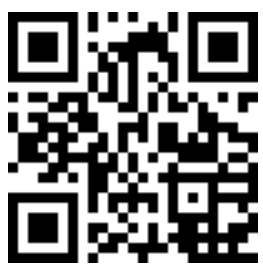

ORCID

(1) 0000-0002-0351-9807

Vital José Pessoa

Madruga Filho

(D) 0000-0003-4775-7775

Reinaldo Farias Paiva

de Lucena 
demonstrating how the audiences are conducted, measuring the effectiveness of the population's participation in this process. Regarding the results, it is expected that the principles from participatory democracy inserted in the public audiences can influence this important democratic tool, avoiding that its adoption becomes just another formal and bureaucratic characteristic to reach the desired environmental license.

Keywords: National Policy on the Environment; Environmental licensing; Popular participation.

\section{Introdução}

Diante dos aspectos que norteiam a participação popular nos procedimentos de licenciamento ambiental, evidencia-se o "direito ao meio ambiente ecologicamente equilibrado", previsto no art. 225, da Constituição Federal (Brasil, 1988), que só pode ser implementado através das ferramentas jurídicas oponíveis à proteção e tutela do meio ambiente.

A partir da repartição constitucional de competências, a proteção ambiental é matéria afeta a todas as unidades federadas, tanto à União, quanto aos Estados, ao Distrito Federal e aos Municípios, de modo que a competência concorrente firmada pelo texto constitucional a estes entes federativos possibilite-os de legislar sobre proteção ambiental e controle da poluição, sem qualquer particularidade temática.

Desta feita, cumpre ao poder público o dever de realizar o controle ambiental das atividades com capacidade de causar impactos ambientais expressivos, bem como àquelas que façam uso dos recursos naturais, cuja ação será evidenciada através de estudos ambientais que vislumbrem eventuais danos ao meio ambiente. A partir disso, o Poder Público deve emitir uma autorização para o funcionamento de tais atividades, conhecida como licença ambiental (art. 3ํ, Resolução CONAMA no 237/1997) (Brasil, 1997), categorizada como um mecanismo de proteção e tutela ao meio ambiente, e instrumento legítimo da Política Nacional de Meio
Ambiente (PNMA), cujo escopo é o de prevenir a ocorrência de danos ambientais (Siqueira, 2008).

Dentre as diversas fases assumidas pelo procedimento administrativo de licenciamento ambiental, figura-se a audiência pública, que denota o cume da participatividade populacional na condição de oferecer julgamento sobre a (in)viabilização do projeto a que se pretende empreender, o qual deverá acarretar em alterações, danos e impactos ao meio ambiente (Ayres Britto, 1992).

A oportunidade em que a audiência pública acontece, nos autos do processo administrativo, é questionada por alguns estudiosos (Bim, 2016), uma vez que no momento em que acontece a reunião pública, os entes interessados já têm despendidos somas pecuniárias direcionadas em estudos e projetos, de modo que a população consultada, muitas vezes, já se encontra "conformada" pelas ideias de desenvolvimento a ser propiciado pelo empreendimento. Por essa razão, a audiência pública acaba assumindo uma via de mero cumprimento de requisito formal exigido pela legislação vigente, para alcance do almejado licenciamento ambiental, fazendo perecer a sustentação democrática que envolve o debate público que deveria ser assumido durante as audiências.

Como é cediço, a Superintendência de Administração do Meio Ambiente do Estado da Paraíba (SUDEMA) é uma autarquia estadual criada pela Lei no 4.033/1978 (Paraíba, 1978) e possui por finalidade o desenvolvimento de uma política de 
proteção ao meio ambiente, exercendo o múnus do controle ambiental na competência circunscricional do Estado da Paraíba.

Diante do exposto, o objetivo principal deste estudo é de analisar a participação da população nos processos de licenciamento ambiental no Estado da Paraíba, sob a égide direcional da SUDEMA. Além do mais, objetiva-se, especificamente, demonstrar que devem ser respeitadas as condições e os limites da lei, para se garantir a proteção e a defesa do meio ambiente sustentável, sendo necessário analisar as faltas/falhas das normas que aludem ao licenciamento ambiental, com ênfase na participação popular por meio das audiências públicas. No mais, é importante elaborar os pontos negativos da atual metodologia adotada pela SUDEMA, identificando os problemas existentes nas audiências públicas e propor uma alteração legislativa a fim de adequá-los à finalidade prevista na norma que garante a participação da população na prolação de licença ambiental. Importa, também, demonstrar a falta de conhecimento apropriado da população para discernir com propriedade sobre os reais riscos do impacto ambiental, a ponto de questionar a legitimidade de tais audiências públicas.

Por tais motivos, é proposta do presente artigo, avaliar a participatividade da população nas audiências públicas de licenciamento, na qualidade de legítimo instrumento que resguarda a implementação da democracia participativa, cuja importância e relação é inconteste, por tratar de assuntos difusos, como é o caso das questões ambientais, as quais envolvem as presentes e futuras gerações, que legará eventual degradação ambiental, a médio e longo prazo, o que de certo poderá arriscar a perpetuação da vida humana no Planeta.

\section{Metodologia}

\section{Delimitação e caracterização da área de estudo}

Para um aprofundamento mais acurado do tema, fez-se mister realizar um recorte espacial e temporal, a fim de delimitar a temática abordada.

Nesse diapasão, o objeto de estudo foi a análise da participação da população nos processos de licenciamento ambiental na Paraíba, em que buscou-se compreender a abordagem das audiências públicas perante $\mathrm{o}$ licenciamento ambiental na Paraíba.

O Estado da Paraíba possui área de 56.467,239 $\mathrm{km}^{2}$, além de uma densidade demográfica de 66,70 $\mathrm{hab} / \mathrm{km}^{2}$, segundo dados do IBGE (2018).

A Região Metropolitana de João Pessoa, instituída pela Lei Complementar no 59/2003 (Paraíba, 2003), alterada pela Lei Complementar no 90/2009 (Paraíba, 2009) e pela Lei Complementar no 93/2009 (Paraíba, 2009), é a área mais desenvolvida do Estado da Paraíba, possuindo o polo industrial concentrado e mais avantajado do que em outras regiões, de onde brotam as maiores demandas para instalação de empreendimentos de grande porte.

Outro aspecto que merece uma maior atenção, diz respeito aos diferentes patamares de Índice de Desenvolvimento Humano (IDH) das cidades que compõem a Região Metropolitana de João Pessoa, além do PIB per capita da população envolvida, que podem influir na tomada de decisões da população, que refletem o nível de formação dos indivíduos partícipes das audiências públicas.

\section{Métodos e técnicas}

Para aprofundar e promover o devido estudo acerca da temática ora apresentada, foi necessário o estabelecimento de uma pesquisa teórica 
e bibliográfica, valendo-se dos meios procedimentais oferecidos pelo método dedutivo, partindo de uma análise geral do tema natureza jurídica do licenciamento ambiental, para uma particular participação popular nos procedimentos administrativos, como forma de oferecer embasamento teórico sobre o assunto, e, posteriormente, compreender com maior distinção as peculiaridades que lhe são inerentes. Foram, assim, consultadas doutrinas, jurisprudências, legislação, regras e princípios, fato que justifica o uso da técnica de pesquisa da documentação indireta.

Pelo método dedutivo, no caso em tela, tem-se uma normativa ampla e genérica que disciplina a realização da audiência pública no licenciamento ambiental, de modo que o cerne do estudo é avaliar a eficácia desse instrumento.

Com relação aos procedimentos de estudo, num primeiro momento foi realizado o levantamento do material bibliográfico, o que inclui consultas às doutrinas, jurisprudências, legislação, regras, princípios, dispostos em livros, revistas, artigos, periódicos e textos pesquisados pela internet. De igual modo, a pesquisa documental, evidenciada a partir das consultas que foram empreendidas junto à SUDEMA, no sentido de angariar informações oficiais acerca dos métodos praticados pela autarquia estadual.

A partir desse momento, foi possível verificar o grau de interferência que a participação popular exerce sobre o licenciamento ambiental; se de fato, a população que debate determinada empreitada, é atendida em seus anseios, dúvidas e/ou sugestões.

Com relação à abordagem, foi utilizada a qualitativa, em virtude do elevado caráter social atrelado ao assunto, mostrando-se como a mais adequada, em virtude de preocupar-se com levantamento de dados acerca de assuntos afetos às reações comportamentais, de opinião e de expectativas dos indivíduos envolvidos. Desta forma, serão envidados esforços para se obter exaustivas leituras dos documentos demandados das audiências públicas tramitadas na SUDEMA, no processo de licenciamento ambiental.

0 estudo qualitativo, na medida em que se preocupa com a compreensão de determinado fenômeno onde eles acontecem, visa a extrair informações, com vistas ao entendimento do processo de como elas surgem, que podem ser obtidas de múltiplas formas. No caso concreto, as ferramentas para obtenção dos dados da pesquisa perpassaram pela análise documental e observação.

0 grande desafio da presente pesquisa foi de analisar documentos que não foram submetidos a um tratamento sistemático e analítico, que exigiu da pesquisa capacidade de interpretar a informação.

Sendo assim, quando da análise das atas das audiências públicas, restou patente de como essas reuniões são desenvolvidas, segundo metodologia própria e específica adotada pela SUDEMA. A forma como as pessoas são chamadas à intervenção e de como os seus quesitos são objurgados pela autoridade ambiental, trazem-nos uma compreensão nítida de que essas audiências não veem desempenhado o papel idealizado pelo legislador.

Após obter autorização da Diretoria Superintendente da SUDEMA, foi possível envidar a pesquisa junto ao Centro de Documentação da autarquia estadual ambiental, de onde foram consultados os processos administrativos de licenciamento ambiental que contavam com participação popular.

Extraiu-se desses processos, o formato do convite à população, além da lista de presença das pessoas que acudiam ao chamado para audiência pública, confrontando-se com os fatores que obstam a plena participação popular, a saber: abulia, acracia e apatia política.

Neste sentido, buscou-se demonstrar por ilustrações gráficas, o nível de participação popular difundido 
no plenário das audiências públicas, como forma de tornar a compreensão do tema mais palpável.

Destarte, a pesquisa documental tem por escopo a produção de novos conhecimentos, na medida em que a pesquisa documental então intentada, terá o condão de externar seu conteúdo de forma mais sucinta, na medida em que haverá a conversão de um documento primário para um secundário.

Quanto aos objetivos, esta pesquisa deve ser considerada sob a categoria exploratória, uma vez que busca viabilizar maior intimidade com $o$ tema, na perspectiva de fazê-la explícita. Envolve levantamento bibliográfico e análise de exemplos que estimulem a compreensão. Assume, em geral, a forma de pesquisa bibliográfica (como fonte primária) e documental (como fonte secundária).

As referências ambientais exigem, de per si, conhecimentos multidisciplinares, a fim de propiciar a construção de um pensamento sólido, eivado de alternativas sustentáveis, na construção de um meio ambiente mais saudável. Assim, necessariamente, a temática ambiental revela um caráter interdisciplinar, do qual, o presente tema abarca várias áreas do conhecimento, tais como o direito constitucional, direito ambiental, direito administrativo, economia, sociologia, dentre tantos outros.

\section{Determinantes da lei para garantira proteção e a defesa do meio ambiente sustentável}

0 interesse pela proteção e pelo meio ambiente possui cronologia bastante recente no calendário internacional, de sorte que no Brasil esse desiderato ganhou espaço no ordenamento jurídico interno após a promulgação da Constituição Federal de 1988 (Brasil, 1988), que sobrelevou o "direito ao meio ambiente ecologicamente equilibrado" na categoria dos direitos fundamentais, sem desmerecer a prevalência de legislações federais esparsas anteriores ao texto constitucional (Madruga Filho et al., 2018).

É possível deduzir que a principal questão orientadora do legislador constituinte, alçava-se numa preocupação mundial com relação ao meio ambiente, numa perspectiva que vai além do espaço e habitat, mas na condição de esteio para favorecer o desenvolvimento da vida no Planeta.

\section{Da Política Nacional do Meio Ambiente (PNMA)}

A Política Nacional do Meio Ambiente abarca as diretrizes gerais previstas em lei, que tem por finalidade estatuir as políticas públicas voltadas em proveito do meio ambiente, a serem observadas pelos entes federativos, para torná-las cada vez mais efetivas.

Dessa forma, a PNMA foi criada pela Lei no 6.938/1981 (Brasil, 1981) e exerce função preponderante no ordenamento jurídico ambiental brasileiro, uma vez que versa sobre a sistemática das políticas públicas para o meio ambiente no Brasil.

Os objetivos da PNMA são classificados em geral e em específicos, conforme própria dicção prevista na lei. Todavia, a conjugação dos objetivos (geral e específicos) direciona esta política ambiental para a conjugação dos três pilares fundamentais do desenvolvimento sustentável (defesa do meio ambiente, desenvolvimento econômico e justiça social).

De acordo com o art. $2^{\circ}$, da Lei $n^{\circ}$ 6.938/1981 (Brasil, 1981), o objetivo geral da PNMA pode ser compreendido sob o espectro da preservação, recuperação e melhoramento da qualidade ambiental:

Art $2^{\circ}$ A Política Nacional do Meio Ambiente tem por objetivo a preservação, melhoria e recuperação da qualidade ambiental propícia à vida, visando a assegurar, no País, condições ao desenvolvimento sócio- 
econômico, aos interesses da segurança nacional e à proteção da dignidade da vida humana, atendidos os seguintes princípios: [...].

Com efeito, o art. 4o do diploma legal em cotejo, elenca os objetivos específicos da PNMA:

I - à compatibilização do desenvolvimento econômico-social com a preservação da qualidade do meio ambiente e do equilíbrio ecológico;

II - à definição de áreas prioritárias de ação governamental relativa à qualidade e ao equilíbrio ecológico, atendendo aos interesses da União, dos Estados, do Distrito Federal, dos Territórios e dos Municípios;

III - ao estabelecimento de critérios e padrões de qualidade ambiental e de normas relativas ao uso e manejo de recursos ambientais;

IV - ao desenvolvimento de pesquisas e de tecnologias nacionais orientadas para o uso racional de recursos ambientais;

$\mathrm{V}$ - à difusão de tecnologias de manejo do meio ambiente, à divulgação de dados e informações ambientais e à formação de uma consciência pública sobre a necessidade de preservação da qualidade ambiental e do equilíbrio ecológico;

VI - à preservação e restauração dos recursos ambientais com vistas à sua utilização racional e disponibilidade permanente, concorrendo para a manutenção do equilíbrio ecológico propício à vida;

VII - à imposição, ao poluidor e ao predador, da obrigação de recuperar e/ou indenizar os danos causados e, ao usuário, da contribuição pela utilização de recursos ambientais com fins econômicos.

Dos princípios preconizados acima, depreende-se que os mesmos atendem às diretrizes e anseios relativos ao licenciamento ambiental, os quais devem nortear as finalidades do procedimento licenciatório.

Os princípios da PNMA estão previstos no art. $2^{\circ}$, da Lei no ${ }^{\circ}$ 6.938/1981 (Brasil, 1981), e são eles:
I - ação governamental na manutenção do equilíbrio ecológico, considerando o meio ambiente como um patrimônio público a ser necessariamente assegurado e protegido, tendo em vista o uso coletivo;

II - racionalização do uso do solo, do subsolo, da água e do ar;

III - planejamento e fiscalização do uso dos recursos ambientais;

IV - proteção dos ecossistemas, com a preservação de áreas representativas;

$\mathrm{V}$-controle e zoneamento das atividades potencial ou efetivamente poluidoras;

VI - incentivos ao estudo e à pesquisa de tecnologias orientadas para o uso racional e a proteção dos recursos ambientais;

VII - acompanhamento do estado da qualidade ambiental;

VIII - recuperação de áreas degradadas; (Regulamento)

IX - proteção de áreas ameaçadas de degradação;

$X$ - educação ambiental a todos os níveis de ensino, inclusive a educação da comunidade, objetivando capacitá-la para participação ativa na defesa do meio ambiente.

Estes princípios inspiram ações que capacitam as metas da política ambiental, e sua atuação possui um escopo bem mais restritivo do que os princípios do Direito Ambiental, na medida em que estes servem de sustentação para um ramo da Ciência Jurídica, enquanto que aqueles embasam as diretrizes e o fomento de uma política pública (Farias et al., 2015).

Inicialmente, é preciso ter em mente que os instrumentos da PNMA são as ferramentas disponíveis aos órgãos de proteção ambiental, com o escopo de alcançar os objetivos da PNMA, sendo certo que a política pública ambiental se concretiza pela utilização e manejo desses instrumentos, os quais estão capitulados no art. 9ㅇ da Lei $\mathrm{n}^{\mathrm{o}}$ 6.938/1981 (Brasil, 1981):

I - o estabelecimento de padrões de qualidade ambiental; 
II - o zoneamento ambiental;

III - a avaliação de impactos ambientais;

IV - o licenciamento e a revisão de atividades efetiva ou potencialmente poluidoras;

$\mathrm{V}$ - os incentivos à produção e instalação de equipamentos e a criação ou absorção de tecnologia, voltados para a melhoria da qualidade ambiental;

VI - a criação de espaços territoriais especialmente protegidos pelo Poder Público federal, estadual e municipal, tais como áreas de proteção ambiental, de relevante interesse ecológico e reservas extrativistas;

VII - o sistema nacional de informações sobre o meio ambiente;

VIII - o Cadastro Técnico Federal de Atividades e Instrumentos de Defesa Ambiental;

IX - as penalidades disciplinares ou compensatórias ao não cumprimento das medidas necessárias à preservação ou correção da degradação ambiental.

X - a instituição do Relatório de Qualidade do Meio Ambiente, a ser divulgado anualmente pelo Instituto Brasileiro do Meio Ambiente e Recursos Naturais Renováveis IBAMA;

XI - a garantia da prestação de informações relativas ao Meio Ambiente, obrigando-se o Poder Público a produzi-las, quando inexistentes;

XII - o Cadastro Técnico Federal de atividades potencialmente poluídoras e/ou utilizadoras dos recursos ambientais.

XIII - instrumentos econômicos, como concessão florestal, servidão ambiental, seguro ambiental e outros.

Desta forma, depreende-se que o licenciamento ambiental (inciso IV) é uma das ferramentas de política pública ambiental, cuja instrumentalização é capaz de aferir os impactos ambientais de determinada atividade potencialmente poluidora e indicar as medidas mitigadoras para evitar a degradação do meio ambiente. Nessa esteira, passa-se a abordar esse importante instrumento da PNMA.

\section{o Sistema Nacional do Meio Ambiente (SISNAMA)}

Criado pelo caput do art. $6^{\circ}$, da Lei $\mathrm{n}$ o 6.938/1981 (Brasil, 1981), o Sistema Nacional do Meio Ambiente (SISNAMA) contempla a universalidade de órgãos e entidades dos entes federados (União, Estados, Distrito Federal e Municípios) impelidos da responsabilidade de promover a tutela e defesa do meio ambiente, através de políticas voltadas para a preservação, melhoria e recuperação da qualidade ambiental (Machado, 2004).

0 SISNAMA tem por escopo promover a integração acerca da atuação dos órgãos ambientais, em esfera federal, estadual e municipal, como forma de harmonizar e uniformizar as políticas públicas voltadas para o meio ambiente.

Dessa forma, o Ministério do Meio Ambiente integrado com as Secretarias Estaduais e Municipais de Meio Ambiente, além das entidades da administração pública indireta relacionadas, estão vinculados à observância dos mesmos princípios, ferramentas e objetivos, como forma de atingir maior nível de eficácia e eficiência, além da necessidade de diminuir o número de conflitos administrativos.

Neste sentido, para compreender melhor o funcionamento desse importante sistema nacional administrativo, torna-se imperioso inferir-se da estrutura organizacional do órgão, entabulada pelo art. 6º , da Lei no 6.938/1981 (Brasil, 1981):

I - órgão superior: o Conselho de Governo, com a função de assessorar o Presidente da República na formulação da política nacional e nas diretrizes governamentais para $o$ meio ambiente e os recursos ambientais;

II - órgão consultivo e deliberativo: o Conselho Nacional do Meio Ambiente (CONAMA), com a finalidade de assessorar, estudar e propor ao Conselho de Governo, diretrizes de políticas governamentais para o meio ambiente e os recursos naturais 
e deliberar, no âmbito de sua competência, sobre normas e padrões compatíveis com o meio ambiente ecologicamente equilibrado e essencial à sadia qualidade de vida;

III - órgão central: a Secretaria do Meio Ambiente da Presidência da República, com a finalidade de planejar, coordenar, supervisionar e controlar, como órgão federal, a política nacional e as diretrizes governamentais fixadas para o meio ambiente;

IV - órgãos executores: o Instituto Brasileiro do Meio Ambiente e dos Recursos Naturais Renováveis IBAMA e o Instituto Chico Mendes de Conservação da Biodiversidade Instituto Chico Mendes, com a finalidade de executar e fazer executar a política e as diretrizes governamentais fixadas para o meio ambiente, de acordo com as respectivas competências;

V - Órgãos Seccionais: os órgãos ou entidades estaduais responsáveis pela execução de programas, projetos e pelo controle e fiscalização de atividades capazes de provocar a degradação ambiental;

VI - Órgãos Locais: os órgãos ou entidades municipais, responsáveis pelo controle e fiscalização dessas atividades, nas suas respectivas jurisdições.

A Figura 1 representa a forma piramidal hierárquica do funcionamento do SISNAMA.

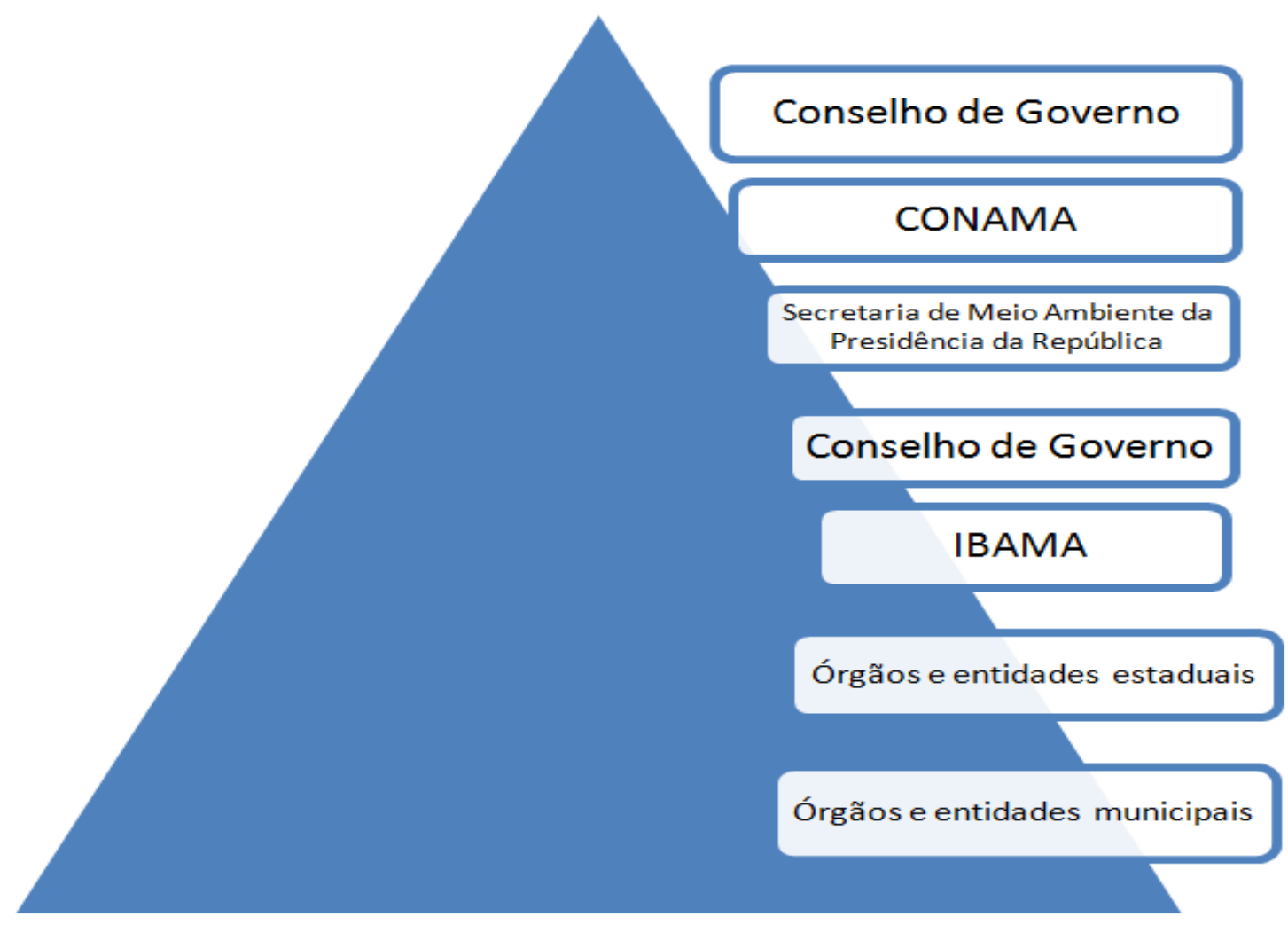

Figura 1. Representação da disposição hierárquica acerca do SISNAMA.

Na condição de órgão consultivo e deliberativo, o CONAMA exerce função proeminente na defesa e proteção do meio ambiente, principalmente pelo fato de ser esse o órgão responsável pela normatização das diretrizes básicas para o licenciamento ambiental. 
O CONAMA é um órgão colegiado, cuja representatividade contempla cinco segmentos da sociedade civil organizada, quais sejam: entidades federais, estaduais e municipais, setor empresarial e sociedade civil.

A importância do CONAMA pode ser exprimida pelas competências legais deferidas ao órgão, na forma do art. $8^{\circ}$ da Lei no 6.938/1981 (Brasil, 1981), c/c art. 7으, do Decreto no 99.274/1990 (Brasil, 1990):

I - estabelecer, mediante proposta do IBAMA, normas e critérios para o licenciamento de atividades efetiva ou potencialmente poluidoras, a ser concedido pelos Estados e supervisionado pelo IBAMA;

II - determinar, quando julgar necessário, a realização de estudos das alternativas e das possíveis consequências ambientais de projetos públicos ou privados, requisitando aos órgãos federais, estaduais e municipais, bem assim a entidades privadas, as informações indispensáveis para apreciação dos estudos de impacto ambiental, e respectivos relatórios, no caso de obras ou atividades de significativa degradação ambiental, especialmente nas áreas consideradas patrimônio nacional.

III - Revogado.

IV - homologar acordos visando à transformação de penalidades pecuniárias na obrigação de executar medidas de interesse para a proteção ambiental;

$\mathrm{V}$ - determinar, mediante representação do IBAMA, a perda ou restrição de benefícios fiscais concedidos pelo Poder Público, em caráter geral ou condicional, e a perda ou suspensão de participação em linhas de financiamento em estabelecimentos oficiais de crédito;

VI - estabelecer, privativamente, normas e padrões nacionais de controle da poluição por veículos automotores, aeronaves e embarcações, mediante audiência dos Ministérios competentes;

VII - estabelecer normas, critérios e padrões relativos ao controle e à manutenção da qualidade do meio ambiente com vistas ao uso racional dos recursos ambientais, principalmente os hídricos.

As formas de atuação do CONAMA se manifestam por meio de cinco modalidades:

$\checkmark$ Resoluções: atos normativos que estabelecem critérios, normas técnicas e padrões de qualidade ambiental;

$\checkmark$ Moções: manifestações de congratulamento ou repúdio;

$\checkmark$ Recomendações: são orientações direcionadas à formulações de atos normativos, políticas públicas ambientais ou programas de governo;

$\checkmark$ Proposições: encaminhamentos direcionados ao Conselho de Governo ou às comissões de meio ambiente da Câmara dos Deputados ou do Senado da República;

$\checkmark$ Decisões finais: como órgão recursal, toma a decisão fatal acerca de sanções impostas pelo IBAMA.

Esta forma de atuação do CONAMA se justifica em virtude deste ser um órgão consultivo e deliberativo, cujo escopo é de solver controvérsias oriundas dos conflitos decorrentes da legislação do meio ambiente aplicável ao caso concreto, a fim de uniformizar as políticas governamentais voltadas para a proteção ambiental, como forma de garantir o necessário equilíbrio socioambiental e promover uma sadia qualidade de vida para os brasileiros (Amado, 2015).

\section{Licenciamento ambiental: conside- rações contextuais}

A doutrina acolhe o licenciamento ambiental como "o mais importante mecanismo estatal de defesa e preservação do meio ambiente" (Farias et al., 2015, p. 106).

0 art. 225, da Constituição Federal (Brasil, 1988) insculpe que "o meio ambiente ecologicamente equilibrado" é um direito fundamental, de 
sorte que o inciso $\mathrm{V}$ do dispositivo constitucional retro citado, impõe ao Poder Público a função de supervisionar as atividades potencialmente poluidoras, capazes de ocasionar impactos ambientais. Deste modo, a sistemática do licenciamento ambiental tende a garantir a prevalência de um meio ambiente ecologicamente equilibrado, na medida em que avalia a instalação e o funcionamento de determinados empreendimentos e atividades econômicas (Almeida et al., 2017, 2019).

Importa suscitar que o art. 9o, IV, e o art. 10, da Lei no 6.938/1981 (Brasil, 1981), impõem às atividades potencialmente poluidoras a submissão ao licenciamento ambiental, cuja instalação e funcionamento são condicionadas à obtenção da outorga ambiental perquirida.

\section{Licenciamento ambiental: um instrumento de proteção ao meio ambiente}

O licenciamento ambiental é um procedimento administrativo e deve ser observado como instrumento hábil de proteção ao meio ambiente, na medida em que limita as atividades capazes de ocasionar degradação ambiental ou que comprometam os recursos naturais, tendo em vista que fixa meios de controle para arrefecer os efeitos oriundos dos impactos ambientais causados pela atividade degradadora, além de estabelecer medidas mitigadoras capazes de neutralizar ou suavizar os possíveis danos ambientais (Bercovici, 2005).

Assim, a preservação ambiental é o ponto nodal do licenciamento ambiental, e é servível para a presente e futuras gerações, conforme dicção exprimida pelo texto constitucional (art. 225). Desta forma, o processo que tenciona a obtenção de uma licença ambiental, calca-se nos pilares alusivos ao desenvolvimento sustentável, nos princípios da prevenção e da precaução, além da avaliação dos impactos socioambientais, conforme lição de Bim (2016).
0 procedimento licenciatório constitui-se através de uma soma de atos administrativos concatenados, e deve perpassar por uma avaliação de impactos ambientais acerca da instalação e do funcionamento de indigitada atividade, cujo cerne subsiste em ferramenta de controle e comando da intervenção antrópica na natureza, sendo imprescindível para a conservação ambiental. Nessa esteira, a participação popular, na condição de ícone da democracia participativa, oferece legitimidade ao procedimento de licenciamento ambiental, quando da análise acerca da (in)viabilidade do deferimento da licença ambiental, haja vista que a tomada de decisões no Estado Democrático de Direito perpassa, necessariamente, pelo crivo das pessoas interessadas e envolvidas no processo em cotejo, para que seja possível assegurar às minorias a oportunidade no diálogo sobre importantes questões ambientais (Modesto, 2006).

Com efeito, a finalidade do licenciamento ambiental é o de coibir a degradação da natureza, oriunda dos impactos ocasionados por atividades a ela associados, de sorte que para que o licenciamento possa atingir o seu desiderato, exige-se serenidade na condução do procedimento administrativo, além da necessidade da implantação de uma sistemática que avalie a qualidade e as ferramentas econômicas das entidades que se submetem ao procedimento licenciatório (Bim, 2016).

Deste modo, infere-se que o mecanismo do licenciamento deve ocorrer sob a égide normativa emoldurada pelo Poder Público, na medida em que cumpre à sociedade o cumprimento e a observância das diretrizes formuladas pela entidade pública, de modo que em eventual transgressão da norma, é cabível a aplicação de uma penalidade, com efeito pedagógico e reparador.

Segundo Milaré (2005), a valorização do licenciamento ambiental 
perpassa pelos princípios constitucionais da prevenção (os impactos podem ser conhecidos previamente, e, portanto, poderão ser atenuados) e do poluidorpagador (caráter reparatório e repressivo). Deste modo, como forma de prestigiar o princípio da prevenção, exsurge a necessidade de oportunizar uma efetiva participação popular, objurgada através de uma intervenção sóbria e consciente das pessoas interessadas.

A tomada de consciência da população em matéria ambiental é primordial para uma apropriada intervenção no procedimento de licenciamento, que perpassa pela capacidade de esclarecimento pessoal acerca dos problemas comunitários, culturais, das tradições e do meio ambiente, exigindo do indivíduo, principalmente, um aprimorado nível de conhecimento em educação ambiental, cuja prática formadora deverá modelar a consciência das pessoas para uma exitosa campanha de preservação ambiental, nos termos elencados pelo art. $2^{\circ}$, $\mathrm{X}$, da Lei $\mathrm{n}^{\circ}$ 6.938/1981 (Brasil, 1981), que objetiva a qualificação das pessoas para uma participação consciente e ativa nos interesses ambientais (Reigota, 2009).

Após a satisfação das exigências normativas cobradas pela legislação em vigor, o interessado poderá obter a perquirida Licença Ambiental, que nada mais é que um ato administrativo, exprimido de um procedimento anteriormente comentado, que poderá ser emitida em três modalidades, quais sejam: prévia, de instalação ou de operação, a depender da fase estabelecida pela atividade empreendida.

Para tanto, a Resolução CONAMA no 237/1997 (Brasil, 1997), estabelece no bojo do seu art. 8으, I, a licença prévia, destinada para a fase de planejamento da atividade a que se pretende empreender. A licença de instalação está versada no inciso II, do mesmo art. 8o da Resolução em comento, e deve ser obtida quando da implantação do projeto da atividade empreendida. Por último, a licença de operação (art. 8o, III), imprime a autorização para o funcionamento do empreendimento, onde se estabelece a autorização para que a atividade empreendida comece a sua operacionalização.

$\mathrm{Na}$ condição de procedimento administrativo, o processo do qual se pretende extrair a licença ambiental, é formado por uma sucessão de atos administrativos orientados e concatenados entre si, estipulados através de diversas fases processuais, a teor do art. 10, da Resolução CONAMA no 237/1997 (Brasil, 1997):

Art. 10. 0 procedimento de licenciamento ambiental obedecerá às seguintes etapas:

I - Definição pelo órgão ambiental competente, com a participação do empreendedor, dos documentos, projetos e estudos ambientais, necessários ao início do processo de licenciamento correspondente à licença a ser requerida;

II - Requerimento da licença ambiental pelo empreendedor, acompanhado dos documentos, projetos e estudos ambientais pertinentes, dando-se a devida publicidade;

III - Análise pelo órgão ambiental competente, integrante do SISNAMA ,dos documentos, projetos e estudos ambientais apresentados e a realização de vistorias técnicas, quando necessárias;

IV - Solicitação de esclarecimentos e complementações pelo órgão ambiental competente, integrante do SISNAMA, uma única vez, em decorrência da análise dos documentos, projetos e estudos ambientais apresentados, quando couber, podendo haver a reiteração da mesma solicitação caso os esclarecimentos e complementações não tenham sido satisfatórios;

V-Audiência pública, quando couber, de acordo com a regulamentação pertinente; VI - Solicitação de esclarecimentos e complementações pelo órgão ambiental competente, decorrentes 
de audiências públicas, quando couber, podendo haver reiteração da solicitação quando os esclarecimentos e complementações não tenham sido satisfatórios;

VII - Emissão de parecer técnico conclusivo e, quando couber, parecer jurídico;

VIII - Deferimento ou indeferimento do pedido de licença, dando-se a devida publicidade.

Neste sentir, é sabido que a sujeição das atividades que devem atentar-se ao licenciamento ambiental depende de eventual geração de impactos ambientais. Sendo assim, a Resolução CONAMA no 001/1986 (Brasil, 1986), visando a garantir objetividade a essas atividades capazes de gerar impactos ambientais, considera como atividade degradadora:

Qualquer alteração das propriedades físicas, químicas e biológicas do meio ambiente causada por qualquer forma de matéria ou energia resultante das atividades humanas que direta ou indiretamente, afetam:

I - a saúde, a segurança e o bem estar da população;

II - as atividades sociais e econômicas;

III - a biota;

IV - as condições estéticas e sanitárias do meio ambiente; e

$\mathrm{V}$ - a qualidades dos recursos ambientais.

Deste modo, a observância dos impactos ambientais torna-se imprescindível para o estabelecimento de medidas de preservação ambiental, uma vez que possibilita o estudo de alternativas tendentes a atenuação dos danos ambientais decorrentes da intervenção antrópica na natureza. Por tal motivo é que o licenciamento ambiental deve ser precedido pelo Estudo Prévio de Impacto Ambiental, que nada mais é do que um dos instrumentos da Política Nacional do Meio Ambiente (Dias, 2003). A avaliação de impacto ambiental pode ser auferida em três modalidades: Estudo de Impacto Ambiental (EIA), Relatório de Controle Ambiental (RCA) ou Plano de Controle Ambiental (PCA).

Desta forma, conforme lição de Bim (2016), ao submeter determinada atividade ao crivo do licenciamento ambiental, o empreendimento que admitir danos ambientais mais expressivos, deverá oferecer Estudo de Impacto Ambiental (EIA), a ser subsidiado, posteriormente, pelo Relatório de Impacto ao Meio Ambiente (RIMA).

Noutra senda, nas situações em que os impactos ambientais não importarem tantos efeitos negativos ao meio ambiente, deverão ser confeccionados o Plano de Controle Ambiental (PCA) e o Relatório de Controle Ambiental (RCA). Este deverá abrigar subsídios acerca da atividade e localização do empreendimento, além das externalidades positivas/negativas decorrentes de tal intervenção, devendo ainda ater-se à adoção de medidas mitigadoras e de compensação ambiental. Já o PCA deverá conter proposta de mitigação, compensação e controle ambiental (Bim, 2016).

O Estudo de Impacto Ambiental é o instrumento técnico competente capaz de estabelecer, analisar e identificar os eventuais danos decorrentes de qualquer atividade empreendida, bem como possibilitar o estudo de medidas de mitigação para combater os impactos gerados pela instalação da atividade econômica (Farias, 2017).

Ao Estudo de Impacto Ambiental (EIA), a Resolução CONAMA no 001/1986 (Brasil, 1986), exige complementação, a ser estabelecida pelo Relatório de Impacto Ambiental (RIMA), uma vez que o EIA apresenta breve escorço intentado ao esclarecimento do público em geral, acerca dos métodos e análises elencadas no próprio estudo, com linguagem mais simplificada e devidamente ilustrada, para atingir a compreensão de todas as pessoas interessadas. 
Em função da relevância que se deve reservar ao procedimento de licenciamento ambiental, é que se deve enaltecer a participação popular na intervenção do processo licenciatório, na esperança de legitimar e conferir eficácia a esse importante instrumento da PNMA. A manifestação opinativa das comunidades envolvidas e afetadas pela instalação de determinado empreendimento produz diversos questionamentos $\mathrm{e}$ motivações no momento da elaboração do RIMA, bem como nas medidas mitigadoras a serem adotadas no intuito de arrefecer os danos e os impactos socioambientais, o que favorece um melhoramento e valorização do projeto a ser desenvolvido em determinada região.

De acordo com o art. $2^{\circ}$, I, da Lei Complementar no 140/2011 (Brasil, 2011), define-se licenciamento ambiental como: "o procedimento administrativo destinado a licenciar atividades ou empreendimentos utilizadores de recursos ambientais, efetiva ou potencialmente poluidores ou capazes, sob qualquer forma, de causar degradação ambiental".

Não obstante a definição legal deferida ao licenciamento ambiental, como:

[...] processo administrativo complexo que tramita perante a instância administrativa responsável pela gestão ambiental, seja no âmbito federal, estadual ou municipal, e que tem como objetivo assegurar a qualidade de vida da população por meio de um controle prévio e de um continuado acompanhamento das atividades humana capazes de gerar impactos sobre o meio ambiente (Farias et al., 2015, p. 131, grifado).

Conforme enunciado do art. $1^{\circ}$, II, da Resolução CONAMA no 237/1997, a licença ambiental é:

[...] ato administrativo pelo qual o órgão ambiental competente estabelece as condições, restrições e medidas de controle ambiental que deverão ser obedecidas pelo empreendedor, pessoa física ou jurídica, para localizar, instalar, ampliar e operar empreendimentos ou atividades utilizadoras dos recursos ambientais consideradas efetiva ou potencialmente poluidoras ou aquelas que, sob qualquer forma, possam causar degradação ambiental.

A licença ambiental é fruto do licenciamento ambiental, que deve ser considerado como processo administrativo complexo, que avaliará a possibilidade ou não de se conceder o ato administrativo de outorga ambiental. Portanto, licenciamento e licença são conceitos que não se confundem, uma vez que aquele se refere a procedimento administrativo sobre $o$ qual serão verificadas as possibilidades de outorga da licença ambiental.

O licenciamento ambiental possui fruição decorrente do poder de polícia de âmbito preventivo, na medida em que visa a exercer o controle sobre atividades potencialmente degradadoras, como forma de tutelar o equilíbrio ambiental e a qualidade de vida das pessoas. Destarte, o controle ambiental deve ocorrer sob critérios estritamente técnicos, como forma de evitar que o perecimento dos recursos ambientais e da qualidade ambiental causem maiores prejuízos à natureza e à sociedade em geral.

Tal desiderato emana do caput, do art. 225, da Constituição Federal de 1988 (Brasil, 1988), que exige do Poder Público e da coletividade o dever de advogar na proteção e preservação do meio ambiente, com vistas à manutenção das presentes e futuras gerações. Diante desse comando constitucional, é possível afirmar que o licenciamento ambiental é a mais importante ferramenta de proteção do meio ambiente, já que é por meio desse procedimento que os órgãos ambientais condicionam e limitam o exercício de cada uma das atividades potencialmente degradadoras. 
Para tanto, o art. 225, V, § 1으, do texto constitucional dota o Poder Público do dever de "controlar a produção, a comercialização e o emprego de técnicas, métodos e substâncias que comportem risco para a vida, a qualidade de vida e o meio ambiente". Portanto, pode-se inferir que a sistemática que rege $o$ licenciamento ambiental tem por escopo garantir que o meio ambiente seja respeitado, em detrimento de atividades potencialmente poluidoras.

\section{Atividades sujeitas ao licenciamento ambiental}

$\mathrm{Na}$ esteira do que estabelece o art. 10, da Lei no 6.938/1981 (Brasil, 1981), o licenciamento ambiental deve ser exigido de "estabelecimentos e atividades utilizadoras de recursos ambientais, considerados efetiva e potencialmente poluidores, bem como os capazes, sob qualquer forma, de causar degradação ambiental”. No que tange aos recursos naturais, sua definição está preconizada no art. $3^{\circ}, \mathrm{V}$, da Lei $\mathrm{n}^{\mathrm{o}}$ $6.938 / 1981$, e diz respeito aos elementos da "atmosfera, as águas interiores, superficiais e subterrâneas, os estuários, o mar territorial, o solo, o subsolo, os elementos da biosfera, a fauna e a flora".

Por outro lado, atividades que possuem capacidade degradadora são aquelas que contam com índices de poluição na consecução do seu mister, de modo que o art. 3ㅇ, III, da Lei $\mathrm{n}^{\text {o }}$ 6.938/1981 (Brasil, 1986) conceitua poluição como sendo:

[...] a degradação da qualidade ambiental resultante de atividade que direta ou indiretamente:

a) prejudiquem a saúde, a segurança e o bem-estar da população;

b) criem condições adversas às atividades sociais e econômicas;

c) afetem desfavoravelmente a biota;

d) afetem as condições estéticas ou sanitárias do meio ambiente;

e) lancem matérias ou energia em desacordo com os padrões ambientais estabelecidos.
Diante de tal conceituação, depreende-se que a compreensão sobre meio ambiente supera os conceitos naturais, abarcando elementos estéticos, econômicos, sociais e sanitários.

Já degradação ambiental deve ser concebida como "a alteração adversa das características do meio ambiente" (art. 3o, III, da Lei no 6.938/1981) (Brasil, 1981), cuja definição supera os parâmetros conceituais de poluição, prova disso é que a definição legal de poluição toma como referência a própria degradação.

Importa destacar que não somente as atividades que geram poluição estão obrigadas ao licenciamento ambiental, mas também todas as outras que possuem potencial de poluição.

$\mathrm{Na}$ esperança de positivar e viabilizar a atuação dos entes e organismos ambientais, o anexo 1 , da Resolução CONAMA no 237/1997 (Brasil, 1997) elencou uma lista exemplificativa de atividades econômicas sujeitas ao licenciamento:

Extração e tratamento de minerais; Indústria de produtos minerais não metálicos

Indústria metalúrgica

Indústria mecânica

Indústria de material elétrico, eletrônico e comunicações

Indústria de material de transporte

Indústria de madeira

Indústria de papel e celulose

Indústria de borracha

Indústria de couros e peles

Indústria química

Indústria de produtos de matéria plástica

Indústria têxtil, de vestuário, calçados e artefatos de tecidos

Indústria de produtos alimentares e bebidas

Indústria de fumo

Indústrias diversas

Obras civis

Serviços de utilidade

Transporte, terminais e depósitos

Turismo

Atividades diversas

Atividades agropecuárias

Uso de recursos naturais 


\section{ental}

\section{Etapas do licenciamento ambi-}

O licenciamento ambiental é procedimento administrativo complexo, dotado de múltiplos atos diretamente relacionados e orientados, cujo objetivo é de aferir se determinada atividade corresponde aos padrões de qualidade ambiental exigidos pela legislação ou pela administração pública ambiental. A fase anterior condiciona a fase subsequente, de modo que ao ser negada a expedição de eventual licença prévia, resta impossível a obtenção da licença de instalação e da licença de operação.

De acordo com o art. 19, do Decreto no 99.274/1990 (Brasil, 1990), o procedimento licenciatório se divide em três etapas, licença prévia, licença de instalação e licença de operação.

A licença prévia (LP) revela a intenção do empreendedor em promover determinada atividade, cuja finalidade é de avaliar a localização e analisar a concepção do projeto, como forma de aferir a viabilidade ambiental do empreendimento. Sendo assim, a LP serve como base fundamental para a ereção e sustentação de todo o projeto a ser implementado (Bim, 2016).

A definição da LP pode ser catalisada por força do art. 19, do Decreto no 99.274/1990 (Brasil, 1990), e o art. 8o, da Resolução CONAMA no 237/1997 (Brasil, 1997), na medida em que essa licença deve ser outorgada na fase de planejamento do empreendimento ou da atividade pretendida, de modo que a eventual concessão dessa licença não permite o início das atividades ou da obra submetida ao crivo do licenciamento ambiental.

Ainda de acordo com o art. 19, do Decreto no 99.274/1990 (Brasil, 1990), e com o art. 8o, da Resolução CONAMA no 237/1997 (Brasil, 1997), a licença de instalação (LI) viabiliza a autorização para o início da execução do empreendimento ou atividade pretendida pelo interessado, de acordo com as especificações dos planos e projetos aprovados, com observância aos condicionantes firmados pelo órgão ambiental. Esta é a segunda fase do licenciamento ambiental, e destina-se a reestruturação do projeto original, que estará dotado de mais especificidades e orientações técnicas no sentido de conjugar a instalação do empreendimento e a defesa e proteção do meio ambiente (Farias et al., 2015, p. 138).

Após análise do cumprimento das condicionantes e das medidas de controle ambiental elencadas nas fases anteriores, a Licença de Operação (LO) se presta a autorizar a operação do empreendimento ou atividade pretendida (art. 19, do Decreto no 99.274/1990, e o art. 8o, da Resolução CONAMA no 237/1997) (Brasil, 1990; 1997).

Trata-se da última etapa do licenciamento ambiental, cujo cume é resultante da análise da sistemática de controle ambiental e monitoramento dos métodos de instalação do empreendimento.

Neste sentido, após a instalação do empreendimento ou edificação da atividade, é competência do órgão ambiental proceder a vistoria da atividade a ser licenciada, como forma de verificar o cumprimento de todas as exigências técnicas de controle ambiental formuladas nas etapas anteriores. Após essa vistoria, serão firmadas outras condicionantes alusivas ao funcionamento da atividade, as quais deverão ser observadas pelo licenciado, sob pena de suspensão ou cassação da outorga ambiental operacional (Farias e al., 2015, p. 138).

\section{Processamento do licencia- mento ambiental}

0 art. 10, da Resolução CONAMA no 237/1997 (Brasil, 1997) estabelece os critérios hábeis para obtenção da licença ambiental. Sendo assim, o processamento seguirá, obrigatoriamente, o seguinte rito procedimental:

I - Definição pelo órgão ambiental competente, com a participação do 
empreendedor, dos documentos, projetos e estudos ambientais, necessários ao início do processo de licenciamento correspondente à licença a ser requerida;

II - Requerimento da licença ambiental pelo empreendedor, acompanhado dos documentos, projetos e estudos ambientais pertinentes, dando-se a devida publicidade;

III - Análise pelo órgão ambiental competente, integrante do SISNAMA, dos documentos, projetos e estudos ambientais apresentados e a realização de vistorias técnicas, quando necessárias;

IV - Solicitação de esclarecimentos e complementações pelo órgão ambiental competente, integrante do SISNAMA, uma única vez, em décorrência da análise dos documentos, projetos e estudos ambientais apresentados, quando couber, podendo haver a reiteração da mesma solicitação caso os esclarecimentos e complementações não tenham sido satisfatórios;

V-Audiência pública, quando couber, de acordo com a regulamentação pertinente;

VI - Solicitação de esclarecimentos e complementações pelo órgão ambiental competente, decorrentes de audiências públicas, quando couber, podendo haver reiteração da solicitação quando os esclarecimentos e complementações não tenham sido satisfatórios;

VII - Emissão de parecer técnico conclusivo e, quando couber, parecer jurídico;

VIII - Deferimento ou indeferimento do pedido de licença, dando-se a devida publicidade.

A Figura 2 ilustra a tramitação dos feitos relativos ao licenciamento ambiental.
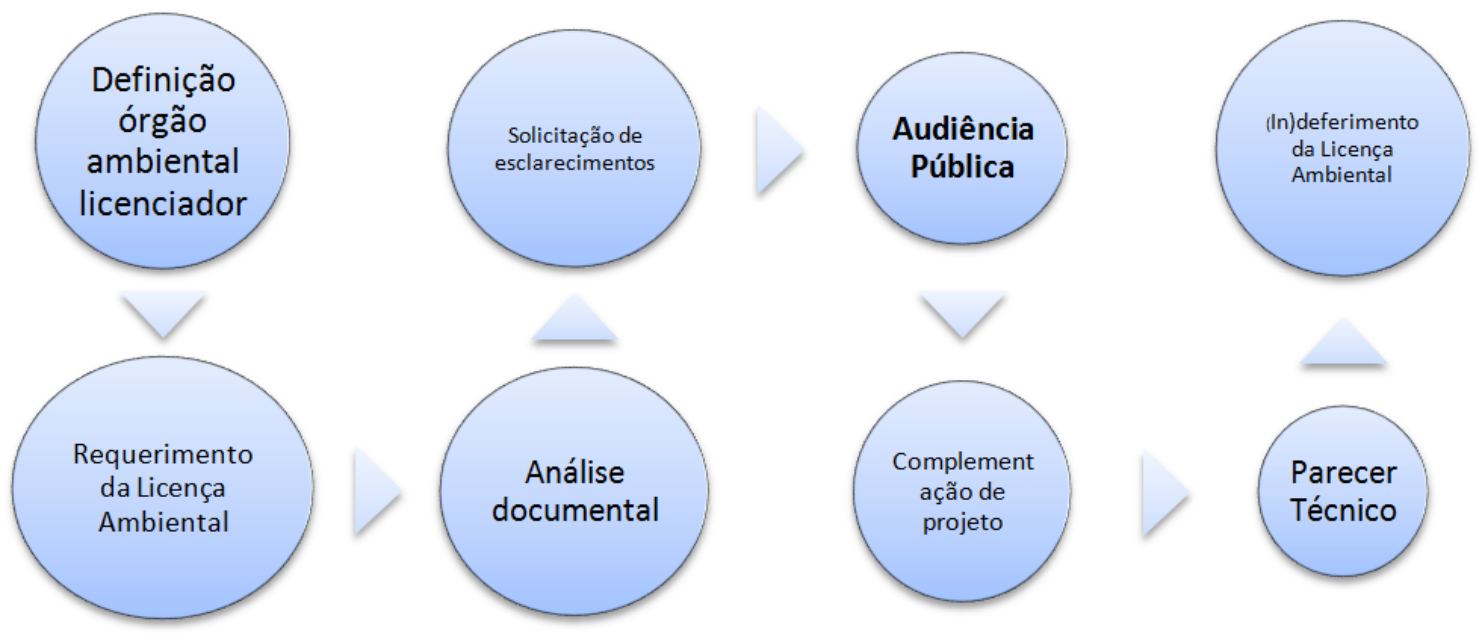

Figura 2. Tramitação dos feitos relativos ao licenciamento ambiental.

Percebe-se que a audiência pública é um item que não vincula todo tipo de licenciamento ambiental. $\mathrm{Na}$ verdade, a participação popular será admitida em procedimentos que avaliem significativos impactos socioambientais, que necessitará de um Estudo de Impacto Ambiental e um Relatório Impacto
Ambiental (EIA/RIMA) mais acurados (Assunção, 2011).

Ademais, em regra, a convocação de audiência pública é uma faculdade do órgão ambiental licenciador, o qual não está vinculado a fazê-lo, tampouco a decisão popular, expressa em plenária 
pública, não vinculará a emissão da licença.

\section{Possibilidade de revisão do licenciamento ambiental}

A licença ambiental nada mais é do que um ato administrativo, fruto de um processo administrativo (licenciamento ambiental), e sendo assim, está passível de alteração superveniente, caso reste demonstrada a ocorrência de eventual erro ou omissão no processamento da licença (Neves, 2014).

Essa característica de revisibilidade é extremamente importante para a compreensão da função que a licença ambiental presta para a preservação e proteção do meio ambiente. Tal possibilidade se funda em três parâmetros bem contundentes, conforme aponta Bim (2016): o primeiro diz respeito ao progresso da ciência e tecnologia, capazes de revelar possíveis riscos ambientais até então desconhecidos; o segundo se refere à parca estrutura dos órgãos ambientais, que contam com limitados índices de recursos humanos e materiais, tornandoos suscetíveis às ingerências políticas, pessoais e econômicas; por último, há a possibilidade de omissão de dados técnicos importantes ou até mesmo apresentação distorcida de planos e projetos, quando da submissão ao licenciamento ambiental, limitando a compreensão do todo ou em parte do projeto e comprometendo a decisão dos órgãos administrativos de meio ambiente.

Desta forma, diante desses elementos comprometedores, a licença ambiental pode ser suprimida do universo jurídico, em caráter definitivo ou temporário, a depender da gravidade macular que lhe foi impingida no curso do seu processo concepcional.

\section{Suspensão da licença}

ambiental. A suspensão da licença ambiental favorecerá o sobrestamento da atividade então outorgada, até que haja a devida regularização com a legislação e as condicionantes ambientais formuladas pelo órgão ambiental. A suspensão será aplicável nos casos em que a atividade se apresente em desacordo com as normas e preceitos ambientais vigentes, capitaneada pelo falseamento ou omissão de informações relevantes inerentes à atividade ou empreendimento, capaz de ocasionar danos ao meio ambiente e à saúde pública. Para a aplicação da suspensão, é preciso restar patente que a correção das falhas detectadas são passíveis de correção, através de medidas de controle e adequação (Farias et al., 2015, p. 138).

A suspensão, que se afigura como retirada temporária dos efeitos da licença no universo jurídico, se funda no princípio da precaução, em razão da possibilidade de existência de algum risco capaz de afligir o meio ambiente e à saúde pública (Amado, 2015). De toda sorte, caso não haja regularização da atividade suspensa, com a devida adequação à legislação e as condicionantes firmadas, a suspensão tornará a retirada definitiva da licença ambiental.

Anulação da licença ambiental. A anulação da licença ambiental é o resultado "de omissão ou falsa descrição de informações relevantes que serviram para fundamentar a expedição da licença" (Farias et al., 2015, p. 145). Dessa forma, como o ato administrativo está viciado em sua fonte, calcado em informações dotadas de frágeis maquinações, impõese a declaração de nulidade.

Cassação da licença ambiental. A cassação ocorrerá sempre que houver desvio de conduta em relação à legislação ambiental aplicável, bem como as condicionantes estabelecidas pelo órgão ambiental licenciador. Sendo assim, a cassação é medida que se impõe quando a atuação da atividade ou empreendimento licenciado correr ao arrepio da legalidade do exercício da atividade que recebeu a outorga ambiental (Bim, 2016). 
Revogação da licença ambiental. A revogação é medida que se impõe sempre que o empreendimento oferecer possibilidade de graves riscos para o meio ambiente e para a saúde pública. Nesse caso, o processo administrativo não foi maculado pelo falseamento ou omissão de informações, mas sim pela possibilidade de risco superveniente à concessão da licença. Como se trata de medida extrema, o risco oferecido deve ser compreendido como sendo insuscetível de recuperação mediante a adoção de medidas mitigadoras e de controle ambiental (Farias et al., 2015).

Aspectos controvertidos entre a democracia participativa e o licenciamento ambiental

A intervenção popular pressupõe a participação de uma determinada comunidade e/ou grupo de pessoas num processo decisório qualquer, na medida em que fica facultada ao cidadão a possibilidade de manifestar-se acerca da formação de normas jurídicas, através do exercício dos direitos políticos que lhes são outorgados, ou até mesmo, exercer comando de influência acerca da tomada de decisões da atividade estatal, cuja participatividade deverá guardar pertinência com os interesses coletivos envolvidos em determinado processo, relegando-se o atendimento de interesses pessoais (Magalhães, 1999). Nesse sentido, é importante que o cidadão esteja dotado e motivado pelos mais nobres sentimentos coletivos, além de imbuir-se dos principais princípios republicanos, que norteiam a atividade estatal, são eles: a legalidade, moralidade, a impessoalidade e a eficiência, para que a sua atuação no processo decisório seja, de fato, eficiente (César, 2011).

\section{Participação cidadã no} licenciamento ambiental. A participação popular no procedimento de licenciamento ambiental possui por finalidade assegurar a preservação ambiental, tendo em vista que o meio ambiente é matéria de interesse geral, e que o direito ao meio ambiente ecologicamente equilibrado é universal, ou seja, oponível a todos, além de ser irrestrito, na medida em que contempla as presentes, bem como as futuras gerações. Desse modo, eventual dano ambiental poderá comprometer os níveis de qualidade do espaço e da vida de determinada localidade (Bim, 2016).

0 interesse geral afeto às questões ambientais, principalmente no que tange ao licenciamento ambiental, analisa a (in)viabilidade do deferimento de licença ambiental para instalação e/ou operacionalização de determinada atividade econômica (César, 2011).

No entanto, é de se ressaltar o receio atinente à ineficácia das audiências públicas no licenciamento ambiental, o que acaba comprometendo a pretendida preservação ambiental. Isto porque, de modo geral, a população escusa-se no direito e no dever de participar desses eventos, em função a ausência de interesse, falta de consciência e cultura para agir em proveito e benefício da preservação e proteção da natureza (Modesto, 2016).

É preciso ter em mente que a faculdade que possibilita a intervenção popular no procedimento licenciatório, é mecanismo de exercício da cidadania, cujo pressuposto funda-se no próprio Estado Democrático de Direito (Bim, 2016).

Como é cediço, o estabelecimento de atividades que importem níveis de degradação e impactos socioambientais, requerem a submissão ao licenciamento ambiental, com base no art. 225, da Constituição da República (Brasil, 1988), c/c art. 10, da Lei no 6.938/1981 (Brasil, 1981), segundo os quais, o poder público é responsável pela fiscalização e o licenciamento daquelas atividades econômicas, além das empreitadas que exploram os recursos naturais (Derani, 2001). 
É que de acordo com o art. 10, da Lei no 6.938/1981 (Brasil, 1981), tem-se a seguinte redação:

\begin{abstract}
A construção, instalação, ampliação e funcionamento de estabelecimentos e atividades utilizadoras de recursos ambientais, considerados efetiva e potencialmente poluidores, bem como os capazes, sob qualquer forma, de causar degradação ambiental, dependerão de prévio licenciamento de órgão estadual competente [...].
\end{abstract}

Desta forma, resta patente a obrigatoriedade à submissão do licenciamento ambiental, de qualquer atividade potencialmente degradadora ou que se valha dos recursos naturais disponíveis.

Com esteio nos princípios da publicidade e transparência, a fim de garantir o conhecimento da comunidade em geral, todas as etapas do procedimento licenciatório deverão ser veiculadas nos veículos de publicidade oficial e em jornal de grande circulação, até mesmo para assegurar a oportunidade de questionamentos e impugnações às questões controvertidas e que causarem discordâncias por entre as pessoas interessadas (Bim, 2016).

Consoante disposto no art. 9o, III, da Lei no 6.938/1981 (Brasil, 1981), a Avaliação de Impacto Ambiental, conforme aduzido em tópico anterior, possibilita subsídios necessários e adstritos à proteção ambiental, cujo estudo pode ser evidenciado pelo EIA/RIMA, PCA, RCA e PRAD, este último que é considerado como apêndice do EIA/RIMA nos casos específicos que envolvem atividades mineradoras, cujo interesse precípuo é de assegurar a recomposição e recuperação da área degradada. Portanto, o Estudo de Impacto Ambiental acompanhado do Relatório de Impacto Ambiental, precedem o licenciamento, nas situações em que o empreendimento importe relevante degradação ambiental (Dias, 2003).
Neste norte, será de responsabilidade do empreendedor, a apresentação do Estudo de Impacto Ambiental (EIA), que deverá contemplar as eventuais modificações nas características físicas e biológicas do meio ambiente, bem como categorizar os possíveis impactos socioambientais que poderão ser suportados pelos seres vivos de determinada localidade. Desse modo, o Relatório de Impacto Ambiente (RIMA) exsurge na perspectiva de pormenorizar um roteiro abreviado do EIA, como forma de tornar acessível à populações os estudos até então desenvolvidos sobre a pretendida atividade que está prestes a ser licenciada, guardado o sigilo industrial com todas as prerrogativas que lhe são asseguradas por lei (Dias, 2003).

A confecção do EIA/RIMA atende ao princípio constitucional da publicidade, na medida em que torna os dados e elementos obtidos através dos estudos acessíveis à população em geral, para que a mesma reúna as aptidões necessárias para debater e opinar no momento da audiência pública em prol do licenciamento ambiental.

É que de acordo com a Resolução CONAMA no 09/1987 (Brasil, 1987), as audiências públicas possuem por escopo a exposição aos cidadãos participantes, acerca dos resultados constantes no RIMA, a fim de suscitar debates, esclarecer dúvidas e acolher dos interessados as críticas e sugestões acerca do relatório.

(Des)conhecimento do cidadão e o seu discernimento sobre os riscos do impacto ambiental. A dinâmica das audiências públicas é semelhante a uma reunião, de caráter informativo e objetivo, tendente às discussões e debates a respeito do projeto a ser empreendido, bem como busca carrear as manifestações e opiniões dos participantes sobre a implementação de atividades potencialmente degradadoras ao meio ambiente.

Neste espectro, chama-se atenção para o modelo de participação uti cives, 
que segundo Modesto (2006), trata-se da intervenção popular calcada nas pessoas que não possuem vínculos jurídicos com o poder público, mas que exercem atuação sobre organizações e entidades que lidam diretamente com 0 desenvolvimento econômico e social, uma vez que esses indivíduos possuem certa "independência" no momento em que ser-lhe-á facultada a oportunidade de tomar decisões em nome da coletividade.

Nesse sentido, Modesto (2006) ensina que existem duas formas possíveis dos indivíduos exercerem sua intervenção na função estatal: i) participação subjetiva, movida por interesses meramente pessoais, que acaba por se sobrepor ao interesse público, e escapar, portanto, da essência da participação popular propriamente dita; ii) participação objetiva, pela qual o indivíduo é motivado pelos interesses coletivos, e manifesta-se em momentos de elevado nível de crescimento político. Assim, as audiências públicas no processo de licenciamento ambiental atendem, ou deveriam atender, aos pressupostos da participação objetiva, na medida em que as pessoas deveriam olhar mais para os interesses coletivos, em detrimento dos interesses pessoais.

Por sua vez, pode-se afirmar que a participação popular prestigia os mais importantes e altruístas sentimentos da democracia participativa, na medida em que possibilita ao cidadão o poder de intervenção direta no processo decisório, até mesmo para exercer um múnus de controle social sobre a atividade estatal, conforme lição apregoada por Bobbio (2011).

Todavia, o emprego retórico arraigado ao tema participação popular, carreia um sentimento de demagogia muito forte, a partir da constatação de que as finalidades das audiências públicas quedam em verdadeiras frustrações, na medida em que a intervenção dos cidadãos mostra-se insuficiente para a dedução de que em determinado processo decisório, realmente, houve uma tomada de decisão popular orientada e consciente (Bobbio, 2011).

Desse modo, Modesto (2006) destaca alguns empecilhos que obstam o êxito da participação popular, quando da realização de audiências públicas, revestidas sob três espécies: a apatia política, que é caracterizada pela falta de incentivos voltados à intervenção popular em determinado processo decisório; a abulia política, que é a própria rejeição da população à participação popular; e a acracia política, traduzida pela impossibilidade dos indivíduos na participação de qualquer evento de ação cidadã.

No mais, é preciso considerar que a participação popular não apresenta um nível uniforme de características e qualificações, uma vez que a sociedade se apresenta através de diferentes níveis de organização e conhecimento (Habermas, 1997).

Neste sentido, a impossibilidade que limita a participação popular nos processos decisórios, conhecida como acracia política, é um elemento oriundo dos níveis insatisfatórios de escolaridade dos indivíduos envolvidos, além do distanciamento geográfico dos grandes centros, tornando as pessoas vulneráveis e reféns de grupos coronelistas que dominam o cenário político de determinada localidade, o que acabam por impossibilitar o alcance da finalidade do mecanismo de participação popular (Modesto, 2006).

Com relação a ausência de motivação para a participação dos indivíduos nas ações cidadãs, conhecida como apatia política, deve-se considerar a falta de informações e conhecimentos necessários sobre os direitos e deveres inerentes a cada cidadão, decorrente da falta de debates esclarecedores, capazes de viabilizar, mediar e facilitar as discussões e o diálogo das pessoas. Nesse aspecto, é possível verificar que o poder público, bem como as empresas que buscam seu licenciamento junto à administração pública, furtam-se ao 
dever de promover informações sobre os empreendimentos e atividades a serem licenciadas, e tal efeito deve ser observado, ainda, pela desmotivação das pessoas que necessitam do poder público (saúde, educação e etc.) e não encontram soluções e serviços satisfatórios às suas necessidades, além da ausência de um instinto que os impulsione à participatividade, tornando-os inertes e indiferentes à tomada de decisões (Modesto, 2006).

No que tange a abulia política, Modesto (2006) ressalta a descrença que os indivíduos carregam acerca do acolhimento ou não das suas opiniões por parte do Estado, o que enseja a ausência de vontade capaz de levar o indivíduo à participação popular. Noutro contexto, a abulia política também pode ser observada pelos sentimentos irrelevantes com que o indivíduo carreia acerca dos interesses da coletividade, levando-os muitas vezes, ao desprezo e indiferença.

Diante desses três fenômenos, que se revestem em verdadeiros óbices e entraves à participação popular, e, por conseguinte, à implementação de uma democracia participativa, é imperioso valorizar os meios de intervenção do cidadão nos processos de tomada de decisões, oriundos dos órgãos públicos responsáveis pela fiscalização e controle ambiental.

Assim, Modesto (2006) apresenta duas formas de participação popular, capazes de conferir eficácia ao intento, são elas: i) intervenção vinculante, repartida em decisória ou de cogestão e interferência condicionadora, cujas decisões são levadas a cabo pelo ente público, com cumprimento vinculado à decisão tomada pela população; e ii) participação não vinculante, que possui um condão meramente consultivo e/ou opinativo.

Já o modo de participação popular, pode ser dividido sob dois enfoques, quais sejam: i) intervenção consultiva, como é o caso das audiências públicas; e ii) intervenção executiva, de modo que organismos da sociedade civil organizada, como é o caso das ONG's, entidades paraestatais e outras assumem a atuação em determinados segmentos (Modesto, 2006).

Bobbio (2011) destaca diversas ferramentas voltadas à concretização da participação cidadã, como é caso da consulta pública, audiência pública denúncia pública, ouvidoria, ação judicial (in caso, ação popular, ação civil pública, mandado de segurança) e tantos outros.

Os mecanismos hábeis à instrumentalização da participação popular ainda são de utilização discreta na realidade brasileira, dada a falta de conhecimento necessário por parte da população. Tal razão subsiste em virtude de um gravoso problema cultural, que queda no famigerado absenteísmo social, arraigado nas mais espúrias práticas colonialistas herdadas pelo Brasil desde o seu descobrimento, como é o caso do crônico problema da exploração social (reificação humana). Tal situação demonstra que a ausência de intervenção popular, pelos motivos anteriormente declinados (acracia, apatia ou abulia), ocorre devido a um problema social, político, econômico e cultural, antes mesmo de chegar a ser considerado um problema jurídico.

Ademais, deve-se levar em consideração a relação clientelista da população brasileira sob o jugo das elites dominantes, de modo que muitas vezes os interesses privados se sobrepõem ao interesse coletivo, sob uma justificativa distorcida de um falso respaldo popular.

Portanto, resta patente que as dificuldades alusivas a uma efetiva política de preservação ambiental, decorrem dessa valorização do interesse privado sobre o interesse público, de modo que a possibilidade e implementação de uma política voltada ao desenvolvimento sustentável, perde espaço diante da voraz necessidade de atingir níveis de crescimento econômico e riquezas familiares cada vez maiores no cenário geográfico do Brasil. 
Desta forma, é imprescindível impingir à participação popular o corolário de uma atividade derivada do Poder Político, no lugar de reportar-se a ela como um simples exercício de manifestação do cidadão, sob a modalidade de um direito público subjetivo (Ayres Britto, 1992; Modesto, 2006).

Sendo assim, é preciso observar a capacidade intervencionista da população, através dos mais variados mecanismos de participação popular, como um elemento que transcende a órbita jurídica, sinalizando a necessidade de interferência multidisciplinar, capaz de gerir uma conscientização pública e viabilizar maior motivação das pessoas em participar dos processos de decisão, através de uma sólida formação educacional e cultural (Modesto, 2006).

Riscos do impacto ambiental. Diante dos conceitos oriundos de especialistas e do senso comum sobre o que vem a ser meio ambiente e a definição de impacto ambiental, é possível observar que no Brasil, a temática é abordada por uma densa legislação correlata ao tema, que traz consigo múltiplos termos e conceitos sobre meio ambiente, dentre os quais se destaca o impacto ambiental (Agra Filho, 2010).

O conhecimento dos impactos ambientais é necessário e de extrema importância, uma vez que traz a lume as medidas mitigadoras e compensatórias em favor do meio ambiente.

A PNMA conceitua degradação ambiental como sendo a "[...] alteração adversa das características do meio ambiente" (art. 3으, inciso II, Lei $\mathrm{n}^{\mathrm{o}}$ 6.938/1981) (Brasil, 1981).

Nesse sentido, quando se tem uma alteração proveniente das características do meio, que depois de sofrer com a perturbação não possui condições de retornar ao statu quo ante de seu sistema, evidencia-se a ocorrência de impacto ambiental, na medida em que as funções socioambientais desses ecossistemas foram afetadas (Borges, 2009).

Os impactos ambientais podem ser marcados por critérios de transitoriedade ou definitividade, a depender da capacidade de resiliência do meio ambiente (Mirra, 1998).

A Avaliação de Impacto Ambiental (AIA) é um importante instrumento para subsidiar o licenciamento, na medida em que o prévio conhecimento dos danos oriundos de determinada ação antrópica, possibilitará a adoção de medidas de arrefecimento dos impactos que importunam o meio ambiente, de onde será possível, também, estabelecer medidas compensatórias na esperança de neutralizar a degradação ambiental suportada pela natureza (Siqueira, 2008).

\section{Resultados e discussão}

Ao adentrar nas margens propostas pela presente pesquisa, observa-se que a SUDEMA não vem oferecendo azo eficaz à proposta normativa quando da realização das suas audiências públicas, conforme ficará demonstrado mais adiante.

A competência orgânica para $o$ processamento do licenciamento ambiental de atividades com considerável potencial poluidor no Estado da Paraíba, é balizado pela SUDEMA, autarquia estadual criada pela Lei no 4.033/1978 (Paraíba, 1978), que incumbe a entidade autárquica à proteção do meio ambiente e promoção da educação ambiental, dotando o órgão de poder de polícia para viabilizar a fiscalização ambiental.

Conforme suscitado, o ponto nodal da intervenção do cidadão no procedimento do licenciamento ambiental, com vistas à tutela do meio ambiente, é a audiência pública, orientada pelo órgão público ambiental e sob a responsabilidade da empresa empreendedora, os quais ficam adstritos à resolução dos quesitos formulados pela comunidade, que será afetada pela 
instalação do empreendimento pretendido.

No entanto, a fim de satisfazer a finalidade das audiências públicas, é imprescindível que a população se faça presente no momento em que a reunião é realizada, através de um comportamento voltado ao interesse coletivo, à responsabilidade socioambiental, comprometida com o desenvolvimento sustentável e, primordialmente, que seja assegurado ao cidadão o amplo acesso ao conteúdo e informações provenientes da eventual instalação do empreendimento, para que seja oportunizado juízo de viabilidade acerca do deferimento ou não da licença ambiental, na esperança de se manter um debate regular e ávido em discussões, fazendo suscitar questões e soluções para as demandas (Modesto, 2018).

Deste modo, é preciso considerar audiência pública como verdadeiro exercício da cidadania, como forma de suscitar o viés político do cidadão, através do envolvimento multisetorial da sociedade civil organizada, afastando a ideia de que a realização desse evento está atrelada a um significado inócuo e meramente formal advindo do ordenamento jurídico.

A dinâmica dos elementos jurídicos, muitas vezes inviabiliza o êxito e distancia a finalidade das audiências públicas do alcance esperado, em razão dos requisitos e exigências insculpidos à intervenção do cidadão no procedimento licitatório, que acabam por desmotivar o indivíduo a participar da reunião, impondo-lhe um estado de passividade e comodismo (Magalhães, 1999).

$\mathrm{Na}$ verdade, o ímpeto participativo de que se espera do cidadão, não advém de normas jurídicas de efeitos cogentes, mas de um processo sólido de educação e acesso à cultura, capaz de insculpir no indivíduo, uma consciência acerca da importância da sua atuação na sociedade e no Estado em que o mesmo está inserido (Habermas, 1997).
Nesse pórtico, é inevitável o sopesamento dos interesses oriundos do capital privado, evidenciados pelas empresas que se candidatam ao licenciamento ambiental, além do caráter político, capitaneado pelo interesse da comunidade, cujo processo dialético deverá produzir frutos ao licenciamento ambiental, com vistas aos ditames do desenvolvimento sustentável (Derani, 2001).

0 momento oportuno para se garantir e assegurar a discussão sobre a viabilidade do licenciamento ambiental dá-se através da audiência pública, onde é discutido o Relatório de Impacto Ambiental (RIMA), já confeccionado pela empresa, onde apresentam os aspectos degradadores ao meio ambiente atinentes à instalação do empreendimento, e de onde surgem soluções capazes de equalizar os problemas aos interesses sociais (Modesto, 2016). É importante suscitar que a intervenção popular no procedimento licenciatório, além de privilegiar os princípios e conceitos da democracia participativa, garante legitimidade ao feito, em função da dinâmica fundamental do Estado Democrático de Direito, que visa ao atendimento fundamental e maximizado da democracia (Habermas, 1997).

A pesquisa identificou com preocupação o modelo do licenciamento ambiental operado no Brasil, haja vista que a audiência pública ocorre em momento posterior à fase de planejamento, estudos, projetos e etc., de onde a empresa candidata ao licenciamento já envidou vultosas somas pecuniárias na encomendação do EIA/RIMA, de modo que na prática, as audiências não comportam grandes ponderações contrárias à empreitada, na medida em que a população não dispõe de liberdade para discernir sobre a (in)viabilidade do empreendimento, que a essa altura, já permeou ideias de prosperidade financeira para os indivíduos da área adjacente ao empreendimento que busca o seu 
licenciamento, além dos benefícios atrelados ao investimento de infraestrutura para a comunidade (Bim, 2016).

Na verdade, observou-se que as discussões captadas nos feitos administrativos mais adiante tratados, se deram de forma rasa e superficial, sem o devido aprofundamento técnico acerca dos impactos ambientais, sociais e econômicos. Numa relação de diretamente proporcional, a participação popular se dá de forma tímida, sem grandes questionamentos, com perguntas esparsas e limitadas pelo próprio órgão ambiental. Percebe-se, claramente, que as audiências são realizadas com o único propósito do cumprimento do dever legal.

Deste modo, é desafiador exigir uma participação isenta e consciente de pessoas que já estão amoldadas pelos ideais progressistas provenientes da eventual instalação do empreendimento, sem, contudo, focar sequer nos prejuízos ambientais.

Na maioria das vezes, os cidadãos absorvem uma publicidade claramente tendenciosa em favor da instalação do empreendimento, atraídos pelo desejo de alcançar patamares confortáveis e melhorados de desenvolvimento social e econômico para a região aonde habitam, e relegam o pensamento crítico inerente às questões universais, como é o caso do fator ambiental, de modo que a degradação do meio ambiente motivada pela instalação de determinado empreendimento, mesmo com capacidade de atingir e afetar outras regiões, será relegada pela falsa ilusão e distração populacional. Assim, o problema precisa ser encarado através de uma visão holística e fraterna, afastando a ideia de que determinado dano local será incapaz de atingir o nível de qualidade do ecossistema regional, e quiçá universal.

Assim, é preciso refletir sobre o momento em que as audiências públicas ocorrem no procedimento licenciatório, para que assim se possa valorizar essa importante ferramenta de intervenção cidadã, na busca de um meio ambiente ecologicamente equilibrado.

A participação deve ocorrer de forma lúcida, na esperança de legitimar o licenciamento perquirido, na ideia de que a democracia é construída pela liberdade no diálogo, na perspectiva de alcançar níveis de dignidade, mitigação da pobreza e, sobretudo, respeito ao ser humano e ao meio ambiente (Magalhães, 1999).

Portanto, faz-se mister investir massivamente em intentos voltados à conscientização humana, como é o caso da educação ambiental, da educação em direitos humanos e etc., como forma de atingir níveis satisfatórios de cidadania, incentivando-os à participação da vida pública, conscientes do seu papel participativo, como forma de privilegiar a democracia.

O disciplinamento das audiências públicas está preconizado nos termos da Resolução CONAMA no 09/1987 (Brasil, 1987), de modo que a sua realização tem por escopo garantir aos interessados o conhecimento acerca dos dados apurados pelo RIMA, com o objetivo de esclarecer eventuais dúvidas, além de acolher críticas e pretensas sugestões acerca da implantação de determinado empreendimento, que pode ser lesivo ao meio ambiente. Ao certo, essas audiências públicas assumem o formato de verdadeiras reuniões, com finalidade informativa, para propiciar o debate acerca do projeto e agregar possíveis opiniões emanadas pelos partícipes (Guerra e Guerra, 2012).

Antunes (2012, p. 399), ensina que:

[...] a finalidade legal das audiências públicas é a de assegurar que a comunidade afetada seja ouvida sobre o projeto, manifestando sua opinião, sem caráter deliberativo. Busca-se com a audiência que os cidadãos indaguem sobre dúvidas quanto ao EIA - já distribuído previamente - e aos impactos nele previstos. Para a Administração, ela 
tem a função de ser um momento no qual poderá ser feita a aferição das repercussões junto à sociedade, do projeto proposto. Sugestões e críticas podem, e devem, ser feitas assegurando que os administradores possam saber exatamente qual é a opinião popular sobre o projeto.

Conforme afirmado anteriormente, a participação popular figura-se como importante instrumento na proteção ambiental, cujo caráter consultivo não pode induzir a população a admitir a empreitada de determinada atividade, sob pena do acometimento de desvio de finalidade, que de certa forma, comprometerá a lisura e a legitimidade de todo o procedimento licenciatório, por atingir os princípios da legalidade e da moralidade (Mirra, 1998).

As audiências públicas podem ser convocadas em dado momento no processamento do licenciamento ambiental, através de expediente da autoridade ambiental, sempre que julgar conveniente, ou quando for requerida por entidade civil, pelo Ministério Público, ou por 50 ou mais cidadãos (Miranda, 2018). Nesse interim, há de se observar que, no caso de uma solicitação de audiência, que porventura seja desatendida pelo órgão de proteção ambiental, eventual licença não terá validade, nos termos do Mandado de Segurança no 23.800/MS, julgado em 14/11/2002, pelo Supremo Tribunal Federal, com a seguinte ementa:

Mandado de Segurança. Criação do Parque Nacional da Serra da Bodoquena. Declaração de Utilidade Pública de Imóveis Localizados na área do Parque. Exigência Legal de Estudos Técnicos e de Consulta Pública sobre a Viabilidade do Projeto. Alegação de Ofensa ao Art. 22, §2º da Lei 9985, de 18/07/2000: Improcedência.

1. Comprovada nos autos a realização de audiências públicas na Assembleia Legislativa do Estado com vistas a atender a exigência do $\S$ $2^{\circ}$ do artigo 22 da Lei no 9.985/2000.
2. Criação do Parque. Manifestação favorável de centenas de integrantes das comunidades interessadas, do Conselho Nacional da Reserva da Biosfera da Mata Atlântica e da Associação Brasileira de Entidades de Meio Ambiente (ABEMA).

3. Parecer técnico, do Ministério do Meio Ambiente, que conclui pela viabilidade e conveniência da destinação ambiental da área, dada a necessidade de se proteger o ecossistema local, revestido de significativa Mata Atlântica. Zona de confluência entre o Pantanal, o Cerrado e o Chaco, onde se encontram espécies vegetais raras, ameaçadas de extinção. Segurança denegada.

De acordo com os preceitos da Resolução CONAMA no 09/1987 (Brasil, 1987), quando o órgão ambiental toma conhecimento acerca do RIMA, deve fixar edital e o veicular na imprensa local, cedendo prazo mínimo de 45 dias para que a solicitação de realização de audiência pública seja efetuada. Decorrido esse prazo, a convocação é oportunizada de acordo com o juízo de conveniência e oportunidade da autoridade ambiental, de sorte que a audiência deve ocorrer em local acessível às pessoas que se mostrarem interessadas (Baptista, 2007).

Destaque-se que mais de uma audiência pode ser convocada num mesmo procedimento de licenciamento ambiental, nas situações que envolvam consideráveis níveis de complexidade ou em regiões que são afetadas pela implantação do projeto e que cuja comunidade não foi devidamente apercebida pela gestão processual orientadora do licenciamento (Guerra e Guerra, 2012).

As audiências públicas devem ser presididas por um representante do órgão licenciador, que terá a incumbência de tecer sucinta apresentação acerca do projeto e do respectivo RIMA, quando então instaura os debates com as pessoas presentes. Os quesitos eventual- 
mente formulados devem ser respondidos e dirimidos de forma fundamentada, de modo que é imprescindível a presença de um corpo profissional técnico e habilmente qualificado para o exercício de tal mister (Assunção et al., 2010).

Após a exposição do projeto e do RIMA, e superadas as discussões, dúvidas e sugestões apontadas pela comunidade presente, deve ser lavrada uma ata, que é apensada ao RIMA, a fim de ser submetida a análise e parecer técnico do licenciador, no que tange à concessão ou não da perquirida licença ambiental.

Todavia, observou-se que a população sequer chega a ser consultada em feitos dessa natureza, sobre a concessão ou não da licença ambiental, logo, a ata é lavrada após o término da resposta aos questionamentos ofertados pela população. 0 que indica que a normativa não vem sendo atendida, na medida em que a população vem sendo sumariamente ignorada pelas autoridades ambientais.

\section{As principais audiências públicas em licenciamento ambiental perante a SUDEMA}

A Superintendência de Administração do Meio Ambiente (SUDEMA) é uma autarquia estadual criada pela Lei $\mathrm{n}$ 4.033/1978 (Paraíba, 1978), e traz em seus objetivos o dever de zelar pelo desenvolvimento de uma política estadual de proteção ao meio ambiente, através de uma política de prevenção e de promoção da educação ambiental.

De acordo com Moreira Neto (2001, p. 211), pode-se colher as seguintes vantagens na realização da audiência pública, a saber:

1. Evidencia a intenção da Administração Pública de produzir a melhor decisão;

2. Galvaniza o consenso em reforço da decisão que vier a ser tomada;

3. Manifesta o cuidado com a transparência dos processos administrativos;
4. Renova permanentemente o diálogo entre agentes eleitos e seus eleitores;

5. Presença de um forte conteúdo pedagógico, como técnica social de acesso ao poder e ao exercício do poder.

Conforme abordagem carreada no presente estudo, o EIA e o RIMA se mostram como documentos conjuntos, que servem para promover uma avaliação do impacto ambiental em decorrência de pretensa instalação de equipamento potencialmente causador de degradação ambiental, com vistas ao estabelecimento de programas responsáveis pelo monitoramento do empreendimento e para mitigar os efeitos decorrentes dos impactos ambientais.

Ademais, giza a Resolução CONAMA no 001/1986 (Brasil, 1986), que o RIMA deverá ser disponibilizado ao público, e o mais importante, deve ser acessível ao público, para que a população se cerque de um preclaro entendimento das consequências do projeto para o meio ambiente.

Nesse interim, a Portaria SUDEMA/DS no 071/2011 (Paraíba, 2011), estabelece a obrigatoriedade da realização de Audiências Públicas em todos os processos de licenciamento ambiental nos quais se requisitar Estudo de Impacto Ambiental (EIA) e Relatório de Impacto Ambiental (RIMA), o que favorece a intervenção popular no licenciamento ambiental, sob as razões necessárias de promoção de uma gestão participativa, calcada nos fundamentos democráticos e de empoderamento popular.

Ao realizar a necessária pesquisa documental prevista nos procedimentos metodológicos do presente trabalho, foi possível destacar a existência de 13 importantes licenciamentos ambientais com atividades aportadas no Estado da Paraíba. Os dados ora apresentados, revelam um tímido desenvolvimento econômico sediado no Estado da Paraíba, que de forma crônica, sofre demasia- 
damente com a falta de investimentos do setor privado na região, que dificulta o progresso do Estado, além de convalescer uma população que sobrevive sem grandes expectativas de crescimento.

Imperiosa crítica aos RIMA's estudados deve ser ponderada, na medida em que esses estudos se apresentam de forma complexa, cuja compreensão fica a um largo alcance do conhecimento comum, o que destoa com o sentido e as finalidades exigidas pela Resolução CONAMA no 001/1986 (Brasil, 1986), na medida em que é possível observar uma clara diferença nas condições das pessoas e nos representantes dos organismos e entidades partícipes das audiências públicas. Para Agra Filho (2008), a precarização dos debates decorre da ausência de interesse social pontificado no RIMA.

Da análise processual tolhida dos feitos pesquisados, foi possível observar diversas peculiaridades, capazes de reorientar o curso tramitacional do procedimento. No entanto, fato bastante intrigante é que a maioria massiva do público presente nas audiências públicas é de funcionários da própria SUDEMA e de outros órgãos públicos com interesses diretos e indiretos na atividade a ser licenciada, além dos operadores e colaboradores das empresas que desejam licenciar-se. A minoria é composta de populares, cujo teor das perguntas denota a superficialidade do entendimento acerca da atividade a que se pretende licenciar. No mais, depreende-se que a população não é consultada, na maioria dos empreendimentos, sobre a viabilidade ou não acerca da concessão da licença ambiental. Individualmente, passa-se a análise dos processos:

\section{- Processo no 2010-007054}

Trata-se de pedido de Licença Prévia para construção de indústria para fabricação de clíquer e cimento, requerida por CCB CIMPOR CIMENTOS DO BRASIL LTDA.

Não obstante a fragilidade das convocatórias, que sequer alcançam o conhecimento da população, a audiência pública foi presenciada por um número expressivo de pessoas já envolvidas no processo de licenciamento, seja no âmbito da empresa requerente, seja no âmbito da SUDEMA. O que não foge à realidade das demais audiências que se sucedem.

As perguntas suscitadas não levaram a cabo os possíveis e prováveis impactos ambientais, e quedaram numa superficialidade sistemática. Restou disseminado o discurso desenvolvimentista, sob o olhar da atração de emprego e renda para a população do Conde.

Questionado sobre os impactos que a atividade vai desenvolver na região, representante da empresa respondeu da seguinte forma: “[...] os impactos para a sociedade serão 04 (quatro) de grande porte, gerando empregos, renda, impostos, e no impacto ambiental será em relação a um pássaro e a um felino, que habitam a região".

Percebe-se dessa forma que as questões ambientais são subjugadas em detrimento dos "avanços econômicos e de desenvolvimento" a serem oferecidos pela empresa. É como se ideias desenvolvimentistas camuflassem os danos ambientais, impelindo-lhes uma categoria desprezível nas discussões encampadas nas audiências públicas.

Por último, a população não foi consultada sobre a aprovação ou desaprovação do licenciamento do empreendimento, sem ao menos garantir à população a capacidade opinativa acerca da viabilidade do empreendimento. Aliás, essa é uma praxe da SUDEMA em audiências públicas, ignorando as disposições normativas que impõem à consulta popular. 
- Processo no 2012-006754

Cuida-se de procedimento
intentado por TERMELÉTRICA
TERMOPOWER S/A, com o objetivo de implantar duas usinas termelétricas no Município de Santa Rita, localizado na Área Metropolitana do Município de João Pessoa.

O caso em cotejo contou com a participação de 115 pessoas presentes na plateia, que pelo porte do empreendimento atrelado ao potencial poluidor da empreitada, não acudiu a um número razoável de pessoas, que estão distribuídas como demonstrado na Figura 3.

Um empreendimento desse porte, na audiência pública que foi realizada, contou apenas com três questionamentos, cujas perguntas eram pertinentes, porém as respostas foram triviais e insatisfatórias, na medida em que não adentraram adequadamente na temática questionada, como se vislumbra do excerto abaixo colhido da ata da audiência encartada no processo em cotejo:

“[...] formada a nova mesa, sendo convidados o diretor técnico da SUDEMA, o Sr. Ieure Rolim, a sra. Adriana de Puglia e o representante da equipe que elaborou o EIA-RIMA, o sr. Wagner Gláucio Amorim. A sra Adriana de Puglia falou brevemente da importância do empreendimento para a região e para o Estado, sendo logo em seguida dada a palavra ao sr. Carlos Alberto Marques dos Anjos, representante da empresa que elaborou o EIA-RIMA, que em 60 (sessenta) minutos expôs aos presentes o Relatório de Impacto no Meio Ambiente. Após a apresentação, foi dado um intervalo de 15 (quinze) minutos onde foi servido um coffeebreak e distribuídos os formulários para os questionamentos da plateia aos responsáveis pelo empreendimento e técnicos que produziram o
EIA-RIMA. [...] em seguida, o sr. Henrique Gutierrez representante do COPAM, questiona qual será a logística usada no transporte de combustível e a distância das unidades de conservação e também em relação aos parques, a representante do empreendimento respondeu que o combustível virá do porto de Suape e entregue pelos caminhões e sobre as unidades de conservação próximas, foi respondido que a preocupação é com as comunidades próximas da unidade, já que as unidades de conservação não tem grande proximidade com o empreendimento. Logo após, o sr. Werison da PMSR porque não foi utilizado no projeto a possibilidade do gás natural que é uma fonte de energia limpa, e o encanamento passa próximo ao empreendimento o sr. Marcelo Weick respondeu que o Governo Federal no processo licitatório já reza que o combustível deverá ser o óleo combustível que é preparado para esse fim. 0 sr. Sílvio Alves de Moraes em seguida externa a preocupação da proximidade com $o$ Rio que é relativamente próximo bem como do lençol freático, e em relação à reserva de mata atlântica, e se haverão recursos para a recuperação da mata, o sr. Carlos responde que existe um aquífero, mas ele se encontra a $60 \mathrm{~m}$ de profundidade, e que em relação à compensação ambiental existe na legislação federal, e que ela haverá que de acordo com as leis vigentes, complementando, a sra. Adriana de Púglia afirma que a lei prevê um cálculo da compensação ambiental e o valor se aplica próximo ao empreendimento, o questionador pergunta agora da origem da água usada no empreendimento, se é do rio, e foi respondido que ela será captada de poços e que ela será reutilizada em um circuito fechado dentro do empreendimento". 


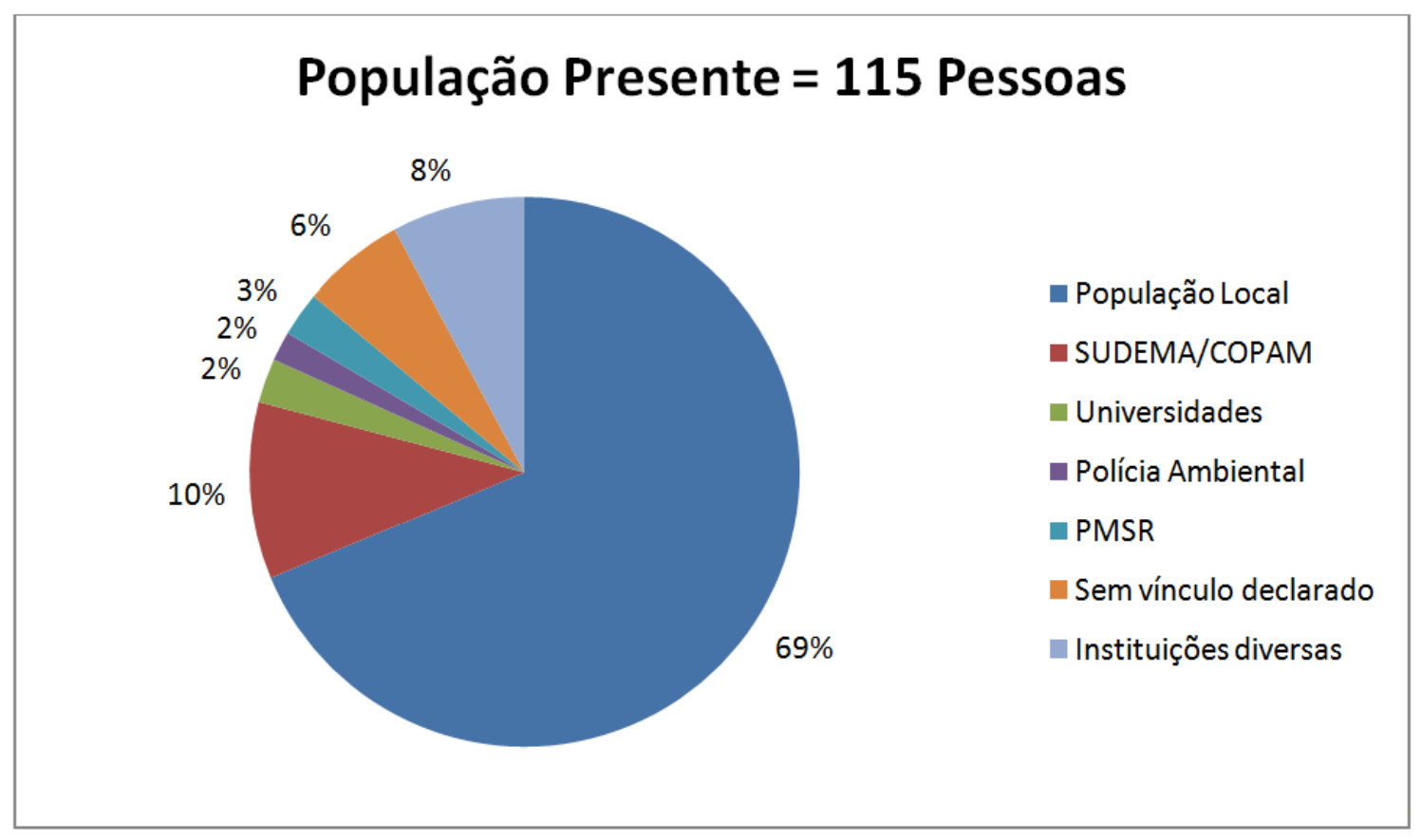

Figura 3. População presente na audiência pública do processo de licenciamento da empresa TERMELÉTRICA TERMOPOWER S/A, com o objetivo de implantar duas usinas termelétricas no Município de Santa Rita-PB.

A baixa participatividade das pessoas na presente audiência, em termos quantitativos, deve-se pela ausência de comunicabilidade do órgão ambiental, que certamente não envidou esforços suficientes para acudir um número razoável de populares, bem como a falta de conhecimento técnicoprévio das pessoas acerca do empreendimento. Um auditório com 115 pessoas, ser formulado apenas três quesitos, é um número muito tímido.

Assim, percebe-se a presença de apatia política, na medida em que as pessoas sentem-se desconfortáveis em manifestar suas opiniões e questionamentos, por acreditar que suas considerações são impertinentes, além da acracia política, que por motivos de conveniência das entidades responsáveis pela realização da audiência pública, não fez chegar o seu convite à população local. Ademais, nota-se a ausência de debates esclarecedores acerca dos questionamentos então suscitados, principalmente no que tange ao quesito formulado pelo sr. Sílvio Alves de Moraes, que contou com uma resposta extremamente trivial.

Mais uma vez, a população não foi consultada sobre a concessão ou não da licença ambiental, veja-se:

\footnotetext{
"Não havendo mais nenhum questionamento, o sr. Ieure Rolim declara encerrada a Audiência Pública e agradece a todos os presentes. Em seguida, foi lavrada a seguinte ata por mim, Erickson Lima Ribeiro, secretário executivo da comissão de EIA-RIMA e assinada pelos présentes. Santa Rita, 12 de novembro de 2012".

Portanto, fica demonstrado que a população margeia o processo decisório, sem ao menos opinar a cerca da (in)viabilidade do pretenso empreendimento, em contrassenso ao que a legislação
} vigente arrazoa. 


\section{- Processo no 2013-001946}

A Companhia Brasileira de Vidros requereu da SUDEMA emissão de Licença Prévia, com a finalidade de promover extração de areia no Município de Caaporã.

A audiência pública contou com uma densa participação de pessoas ligadas a uma empresa de consultoria ambiental, contratada para realizar os estudos e acompanhamentos procedimentais, de funcionários da própria SUDEMA, do Município de Caaporã e de empresas com interesses diretos e indiretos na emissão da licença ambiental (Figura 4).

\section{População Presente $=53$ Pessoas}

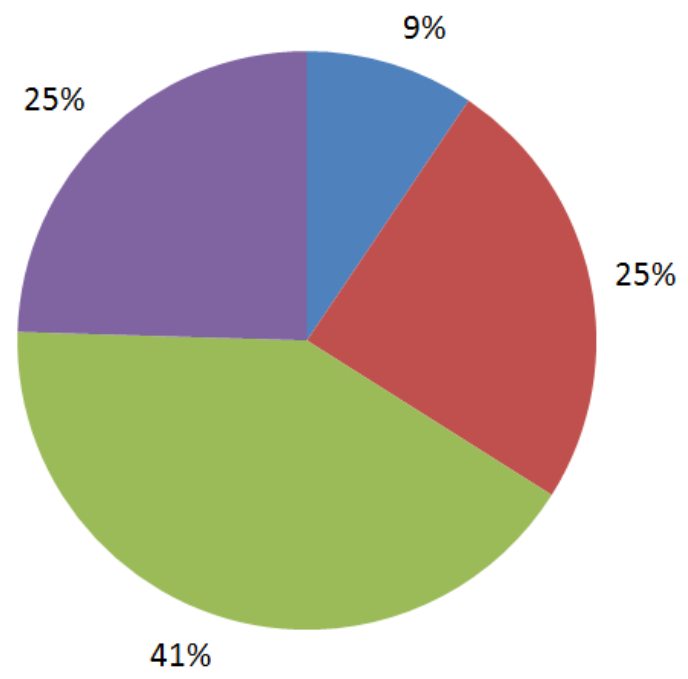

- População Local

- SUDEMA/COPAM

nórgãos Públicos

Empresa de Consultoria

Figura 4. População presente na audiência pública do processo de licenciamento da empresa Companhia Brasileira de Vidros, com a finalidade de promover extração de areia no Município de Caaporã.

0 debate foi extremamente viciado, na medida em que o auditório estava permeado por membros da empresa de consultoria que confeccionou o EIA/RIMA, além de representantes do órgão estadual licenciador.

No caso vertente, sequer o RIMA foi disponibilizado, nem física e nem eletronicamente, ou seja, o documento hábil que enseja as discussões numa audiência de EIA/RIMA não foi oferecido previamente, em flagrante arrepio às normas atinentes à participação popular em licenciamento ambiental, estando apenas disponível no sítio eletrônico da SUDEMA.

Durante a audiência, foram colhidas algumas sugestões formuladas pelos populares, dentre as quais se destacam a distribuição de mudas para o Município de Caaporã, além da implementação de um plano voltado para a educação ambiental. Acerca de tal sugestão, não foi dado qualquer posicionamento. Acerca de questionamento sobre reposição florestal, foi envidada a seguinte resposta: "que tramita paralelamente o processo de uso alternativo do 
solo, e que a decisão, após o parecer técnico será levado ao IBAMA para decisão daquele órgão". Trata-se de uma tergiversação sem objetividade alguma, nada se explicou sobre a dúvida aventada pelo cidadão, num manifesto sintoma de abulia política.

Em pergunta formulada por outro cidadão sobre os impactos ambientais negativos, a resposta foi a seguinte: "[...] em uma apresentação não é possível esmiuçar todos os impactos, mas que estas informações constam no RIMA que estará à disposição na SUDEMA". Ou seja, como o RIMA não foi devidamente apresentado à população, não se conhecia os impactos ambientais que a empreitada importaria para o local, tampouco o debatedor conseguiu expôlos, supondo-se um certo despreparo na condução dos trabalhos.

Não houve submissão ao crivo da decisão populacional, que sequer foi consultada sobre a viabilidade ou não da concessão da licença ambiental.

\section{- Processo no 2013-003908}

Trata-se de pedido de outorga de licença prévia, formulado pela VOTORANTIM CIMENTOS N/NE S/A, com o intento de licenciar sua atividade de fabricação de cimento, na zona rural do Município de Caaporã.

Acerca da lista de presença, a mesma não foi encontrada nos autos do processo em epígrafe, o que prejudica a demonstração gráfica dos presentes e das instituições a que as pessoas eram vinculadas quando da realização da audiência pública.

Depreende-se da ata da audiência, que diversos quesitos foram suscitados pelo público presente, de forma objetiva e pertinente. Os debates foram enriquecedores, na medida em que clareou as dúvidas da população.

As principais questões suscitadas pela população presente, dizia respeito ao caráter socioeconômico do empreendimento, de sorte que questões ambientais não foram densamente exploradas durante a audiência pública. Perguntas acerca do volume de capital a ser investido, quantos empregos a empreitada iria gerar e etc. Com vistas a degradação ambiental, a empresa informou a realização de um Plano de Recuperação de Áreas Degradadas, e explicou a metodologia de sua implantação no local.

Ao final, o presidente da mesa afirmou que a finalidade da audiência era apenas de apresentar o estudo ambiental à população, sujeito a alterações oportunas sugeridas pelos cidadãos ali presentes, como forma de subsidiar o processo de licenciamento ambiental.

$\mathrm{Na}$ verdade, as audiências públicas possuem um caráter opinativo e não vinculatório, de modo que a população precisa ser consultada sobre a viabilidade ou não da concessão da licença ambiental.

\section{- Processo no 2015-005857}

Cuidou-se de pedido de outorga de Licença Prévia, com o objetivo de promover a duplicação de rodovias entre Campina Grande, Queimadas e Alcantil, tendo como requerente o Departamento Nacional de Infraestrutura de Transportes (DNIT). Como de praxe, foram emitidos convites específicos às autoridades e algumas entidades públicas e privadas, escolhidas pela própria SUDEMA. Conforme reza o texto normativo da Resolução CONAMA no 09/1987 (Brasil, 1987), o edital convocatório para a audiência pública foi publicado no diário oficial e em jornal impresso de grande circulação, no caso o jornal estatal A União.

Repise-se que a convocação da população por meio de jornal impresso é prática demasiadamente obsoleta, na medida em que uma ínfima porção da população recorre a esses meios de comunicação. Atualmente, existe uma série de canais de comunicação com alcance muito maior e efetivo. 0 resultado natural é que a população não acudiu ao convite (Figura 5). 


\section{População Presente $=45$ Pessoas}

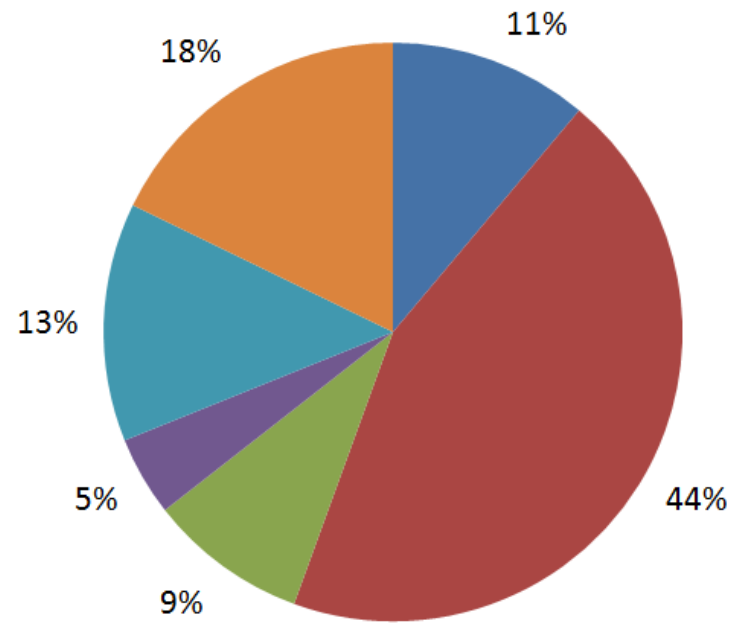

- População Local

- SUDEMA/COPAM

DNIT

口MPB

- Sem vínculo declarado

- Instituições diversas

Figura 5. População presente na audiência pública do processo de licenciamento da empresa VOTORANTIM CIMENTOS N/NE S/A, com o intento de licenciar sua atividade de fabricação de cimento, na zona rural do município de Caaporã.

0 baixo número de pessoas interessadas na audiência pública é reflexo de um parco convite, atrelado à ideia local de que a participação das pessoas pouco influenciará no resultado dos debates, que considera o ato uma possível perda de tempo. Nesse caso, observa-se a presença da abulia política, caracterizada pela ausência de motivação para a participação dos indivíduos na ação cidadã.

No que diz respeito à dinâmica das audiências, deve-se extrair o seguinte trecho da ata da audiência pública:

“[...] tomando a palavra, a presidente da mesa, Cristiana Cavalcanti (SUDEMA) deu início aos trabalhos e passou a palavra para Gilson Marinho que em quinze minutos o empreendedor falasse de forma geral sobre o empreendimento, após a breve apresentação, o sr. Silar Werner em sessenta minutos relatou detalhes sobre o relatório de impacto ambiental para a audiência presente.
Findada a apresentação, foi dado um intervalo de quinze minutos para que os presentes pudessem elaborar seus questionamentos a respeito do relatório apresentado. Terminado o período de intervalo, a mesa foi recomposta com a sra. Naya Caju, Sra. Cristiana Cavalcanti, além dos representantes do Empreendimento já citados, sendo iniciado o período de questionamentos feitos pelos presentes e dirigidos aos representantes do empreendimento. [...] a primeira questão elaborada pela srta. Silvana de Souza, do município de Queimadas que como devem proceder os interessados em ter acesso ao material do EIA-RIMA para consulta, sendo respondido pela Dra. Naya Caju que o material de consulta estava disponível nas prefeituras de Campina Grande e de Queimadas, e que o DNIT também disponibiliza o material para consulta, Arnaldo Maja do município de Queimadas qual critério que o DNIT para os retornos, e respondido 
que em toda extensão da rodovia serão feitos retornos a cada $3 \mathrm{~km}$, Sidney Oliveira do Instituto de Cooperação Agrícola questiona quanto a mobilidade urbana e questões socio-econômicas que foi levado em consideração esses pontos, respondido que foram obtidos dados junto as prefeituras e que $o$ processo de debate foi estabelecido pela SUDEMA e que em relação a mobilidade foram contemplado no EIA e caso haja a necessidade de dados complementares junto a Sudema, o empreendimento levantará as demandas solicitadas, na réplica o questionador levanta questão que pode contribuir mais nas questões de mobilidade, relatando um dos representantes do empreendimento que disponibilizará seu contato pessoal para receber sugestões e esclarecimentos adicionais sobre o tema. Outra questão foi sobre a criação da APA se o plano diretor será elaborado, a Dra. Naya Caju responde que é uma propositura do EIA e na SUDEMA dispõe de uma câmara de compensação ambiental e que a criação é uma sugestão e que deverá ser analisada e que a decisão não cabe a comissão de EIA-RIMA, mas que a sugestão será levada em consideração e estudada, e caso ocorra, terá todo trâmite legal atendido incluindo plano de manejo e que esse processo toma o tempo necessário para que ocorra de forma legal, e que todo procedimento tem sua legislação que regula a criação e manutenção. Em seguida foi questionado pelo sr. Flávio pergunta que se foram detectados pontos para passagem da fauna $e$ se haverá resgate na fauna local, respondido que foram detectados pontos de passagem de fauna, que será cerca de oito pontos e que serão feitas também ações específicas também de resgate e soltura em locais determinados após o avanço dos estudos, sendo Sebastião Gonçalves pergunta se seu município na área rural existe projeto para passagem de animais devido ao

\begin{abstract}
grande número de animais atropelados, pois se trata da entrada da cidade e também na área urbana se existirá algum elevado, sendo respondido que não existe necessidade de um dispositivo aéreo para passagem de animais, mas que podem ser adotadas medidas mais simples como redutores de velocidade, ou passagens subterrâneas para passagem da flora". (grifado).
\end{abstract}

No ato da audiência, uma das perguntas mais intrigantes foi da senhora Silvana de Souza, que queria saber como ter acesso ao EIA/RIMA. Ora, sequer a disponibilização do material foi realizada, de sorte que a população chegou alheia aos estudos ambientais que foram empreendidos, o que certamente enfraquece e fragiliza o debate. Nesse aspecto, restou patente que não foram envidados esforços suficientes, capazes de deixar a população a par dos debates, limitando-os a um quadro acrático. Assim, está-se diante de fenômeno da apatia, que fragilizou os debates, pelo fato da população não saber com detalhes o que seria discutido, que, por conseguinte, se traduz em acracia também, dada a limitação dos conhecimentos técnicos da população acerca do EIA-RIMA que fora "discutido".

Outro fator que merece relevância é a preocupação da população com a conservação da fauna e da flora, com questões que vão desde a possível criação de uma Área de Proteção Ambiental (APA), como medida compensatória aos danos ambientais oriundos da empreitada, até medidas de mitigação da morte de animas. Percebe-se que a Mesa não estava preparada para essas respostas, chegando ao ponto de um dos membros, oferecer seu telefone pessoal para angariar sugestões e dirimir possíveis dúvidas. Ora, o momento adequado para a resolução das questões e assimilação das sugestões é a audiência pública, após esse marco, preclui-se qualquer intenção modificadora proveniente de demandas populacionais. 
A audiência assumiu um condão meramente esclarecedor, na medida em que a população não foi consultada acerca da aceitação ou não do empreendimento.

\section{- Processo no 2015-007011}

Ao analisar o processo no 2015007011, que trata sobre a instalação de um estaleiro no Município de Lucena, depreende-se que a audiência pública recebeu tratamento responsável $\mathrm{e}$ equilibrado por parte da SUDEMA, na medida em que foram disciplinados diversos pontos sobre a forma de como se realizaria a audiência pública. Houve uma volumosa participação da população, apesar dos meios convocatórios serem os mesmos (jornais impressos). Através da ata colhida pela reunião popular, foi possível verificar que todos os questionamentos formulados pela população local foram suficientemente respondidos pelo representante técnico da empresa, quando ao final, foi submetida aos desígnios populares a aprovação ou não do projeto, que foi aceito, por unanimidade, pela população presente (Figura 6).

\section{População Presente $=168$ Pessoas}

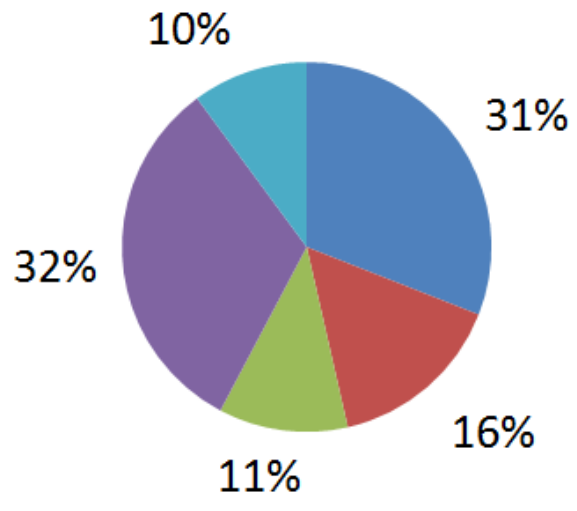

População Local

SUDEMA/COPAM

Universidades

Órgãos Públicos

Instituições diversas

$11 \%$

Figura 6. População presente na audiência pública sobre a instalação de um estaleiro no Município de Lucena.

0 espaço deferido à população contempla o alcance pretendido pelas audiências públicas, que atendeu ao chamado dos órgãos competentes para participar da reunião pública. 0 tema foi amplamente debatido, e a população foi consultada sobre a possível viabilidade do empreendimento.

Os debates perfilharam questões de cunho socioeconômico, na medida em que a população estava tomada pelo sentimento de empregabilidade disseminada pela publicidade do empreendimento.

Por outro lado, questões ambientais também foram densa $\mathrm{e}$ oportunamente debatidas, onde foi detalhado plano de manejo da fauna a ser executado no local e as medidas mitigadoras para arrefecer os efeitos dos 
impactos ambientais provenientes da empreitada.

- Processos nos 2017-006840 e 2017-006847

O comentário de ambos os processos é oportuno, na medida em que suas características apresentam similitude metodológica.

Por outro lado, foi possível observar no bojo dos Processos Administrativos SUDEMA no 2017006840 e no 2017-006847, que tratam sobre a implantação do Centro de
Convenções de João Pessoa e a Renovação da Licença de Instalação do Distrito Industrial do Turismo, respectivamente, uma tímida convocação populacional, através de convites colacionados nos "classificados" de jornais impressos, cuja visibilidade passa muitas vezes despercebida. Além do mais, determinados segmentos da sociedade civil organizada foram agraciados com convites personalizados, para assim participarem das audiências. A representação dos indivíduos presentes na audiência pública é mostrada na Figura 7.

\section{População Presente $=59$ Pessoas}

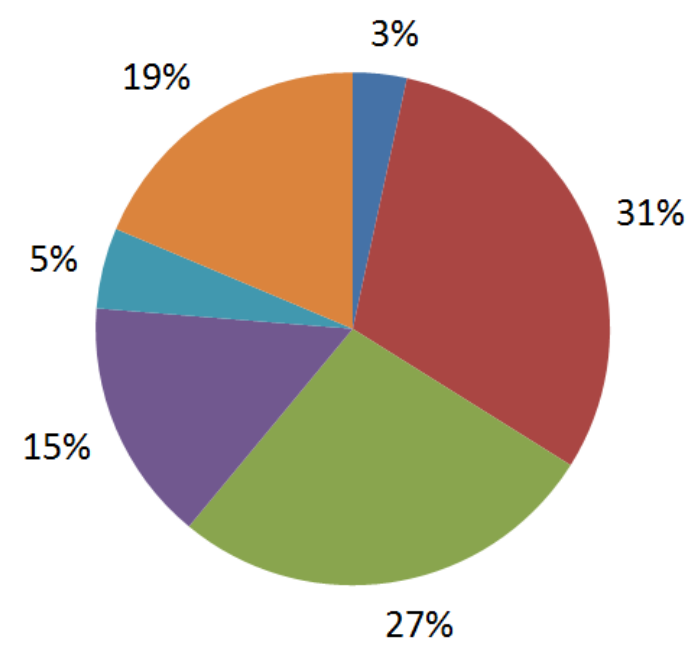

População Local

SUDEMA/COPAM

CINEP

Órgãos Públicos

Sem vínculo declarado

Instituições diversas

$27 \%$

Figura 7. População presente na audiência pública sobre a renovação da Licença de Instalação do Distrito Industrial do Turismo de João Pessoa.

A ausência da difusão de convites, capazes de atrair a população num quantitativo mais aquinhoado, fragiliza o nível dos debates, que exigem um aprofundamento interdisciplinar para um melhorado nível das discussões.

Ao presenciar a audiência pública dos dois processos retro citados, foi possível perceber que os questionamentos da população foram limitados, além do que, nem todas as perguntas levantadas pelos indivíduos presentes foram prontamente respondidas pelos responsáveis pelo empreendimento.

É que a metodologia preconizada pela SUDEMA nos feitos em comento orienta a distribuição de formulários com os questionamentos para que a população possa fazê-lo, os quais, de 
forma seletiva, são escolhidos para serem respondidos pelo responsável técnico pela confecção do EIA/RIMA. Ou seja, nem todas as perguntas foram respondidas.

Ao final, a sensação de que a audiência pública ocorreu como mero cumprimento do dever formal era latente, de modo que sequer estudos acurados sobre a vegetação de mata atlântica que seria suprimida foram fundamentadamente apresentados. $\mathrm{Na}$ verdade, Engenheiro Florestal foi comtratado para demonstrar estudos complementares fitossociológicos da região, cujos resultados foram superficialmente debatidos, apesar da vegetação, conforme estudo apresentado, mostrar-se em fase secundária de regeneração.

Faz-se necessário importar excerto da ata da audiência, para que se possa tecer alguns comentários, a saber:

"Tomando a palavra, Naya Caju (SUDEMA) esclareceu que todos os documentos produzidos nessa audiência pública, farão parte do processo de licenciamento ambiental, e que a licença é concedida pelo COPAM (Conselho Estadual de Proteção Ambiental), e que os estudos estão disponíveis no site da SUDEMA para apreciação pública. Iniciando com a primeira questão de Ronilson da Paz onde questiona sobre o estágio de regeneração a vegetação se encontra. Vital Madruga da OAB pergunta diante da vasta área suprimida qual o impacto no clima urbano da capital, respondido por Ivan Buriti, que apenas 1/4 vezes 4 é que será desmatado e ocupado, sendo que a metade de toda área é de coqueirais, sendo criado unidades de conservação de mais de 500 hectares e que não haverá impactos pois estamos fazendo uma compensação de mais de 10 vezes da área desmatada, e outra pergunta diz respeito ao que tange a criação de uma unidade de conservação onde no Brasil o poder público não trata bem as unidades de conservação, sendo respondido por Fabiano Lucena que apesar das áreas de conservação serem maltratadas no Brasil o Estado tem cuidado desse tema de uma forma mais cuidadosa, cercando áreas de preservação, além do fato de ser feito um enfrentamento do degradador com policiamento ambiental, prisões de quem degrada e várias ações de proteção. 0 procurador Jurídico da Sudema também coloca que a compensação ambiental será usado também para a construção do Batalhão Ambiental. Outra questão diz respeito a contrapartida dos investidores o que foi respondido também por Ronilton Lins que esse licenciamento não diz respeito aos empreendimentos hoteleiros, e que havendo as condicionantes nesses licenciamentos que solicitem essa. 0 empresário Roberto Cavalcante pergunta se algum empreendimento poderia tirar a licença se o Polo não estivesse licenciado, sendo respondido que o polo sempre esteve licenciado e que esses estudoa são apenas complementares, e hoje houve apenas a mudança de agência. Outros esclarecimentos dado por Naya Caju é que a instalação já foi emitida pelo COPAM e houveram condicionantes e foram cumpridas. Ronilton Lins esclarece que o EIARIMA não prescreveu. $0 \mathrm{Sr}$. Holanda relata que em 1990 entrou com um pedido de licenciamento e existia pedencias, sendo respondido por Ivan Buriti que as pendencias foram sanadas. Naya Caju esclarece também que a audiência está havendo em comprimento de um pedido do Ministério Público e até a construção do Batalhão Ambiental estará sendo construído em cumprimento de uma das condicionantes de licenciamento, que a própria comissão de EIA-RIMA poderá após a audiência pública poderá solicitar o seu licenciamento em uma processo na Sudema, e cada empreendimento assim como aconteceu com o Centro de Convenções terá seu processo de licenciamento ambiental. A próxima questão de Wesley Chagas pergunta sobre a retirada dos moradores dos terrenos, sendo respondido que nenhum dos lotes do 
empreendimento está invadido e que isso ocorre apenas em áreas públicas. Larissa Monteiro pergunta se há algum tipo de parcelamento do solo com quadras ou lotes, sendo respondido que está no mapa de planejamento da prefeitura com tudo que é relativo com o código de postura do município. Letícia pergunta sobre a construção desse empreendimento a 300 metros da falésia do Cabo Branco que sofre um processo de erosão, sendo respondido por Ivan Buriti que a falésia é protegida pela constituição Estadual, e que de acordo com a legislação. Existindo no EIA-RIMA a recomendação de um recuo de 100 metros em relação a falésia, sendo o empreendimento tem um recuo bem maior que o recomendado pelo estudo. Paula Franssinete pergunta sobre um EIA-RIMA de mais de 30 anos e o que dizer sobre a recuperação da mata atlântica e do estudo fito-sociológico, sendo ressaltado por Ivan Buriti que o EIA foi feito em 2010, a mesma ainda questiona qual a forma de acesso à praia, visto que a barreira do cabo branco está em perigo e o levantamento faunístico é muito importante e que na opinião da mesma existe muito a ser feito antes da aprovação do projeto, Ivan relata em resposta que a constituição foi mudada. Thainá Lemos da UFPB pergunta se existe população de baixa renda na área, se serão todos realocados ou apenas retirados, sendo respondida por Naya Caju, que as população que está na área de proteção está de forma irregular, e que em 2017 foi constituída a unidade de proteção ambiental de mais de 500 hectares e é possível através da compensação ambiental serem tomadas várias ações como o plano de manejo, levantamento de fauna, flora e demais necessidades, como a educação ambiental e será de atribuição da Sudema. Fabiano Lucena destaca nas áreas invadidas existem imóveis com piscinas e de alto padrão que apenas depredaram áreas de proteção, e se não existir uma ação real, a discussão será vazia e pouco se fará, e que nesta gestão já foram implantadod três planos de manejo nas unidades onde não existia nenhuma anteriormente, e que se a lei for cumprida a proteção ambiental e o desenvolvimento avançará".

Inicialmente, insta suscitar que o relatório de impacto ambiental não foi adequadamente disponibilizado à população presente na audiência pública. Mais uma vez, o material estava ancorado exclusivamente no sítio eletrônico da SUDEMA, impossibilitando o seu manuseio por parte dos cidadãos presentes no auditório.

$\mathrm{Na}$ verdade, o que causou mais espécie, foi que o licenciamento dos empreendimentos em cotejo mais uma vez não foi submetido a uma prévia aprovação por parte da população, o que desfigura o sentido das audiências públicas e compromete a legalidade dos procedimentos, de sorte que as reuniões se prestaram apenas para tirar dúvidas da população, sem levar em consideração a decisão da população local acerca da (in)viabilidade de pretensa instalação de empreendimento que cause potenciais impactos ambientais. Tal situação faz despontar o sentido da apatia política, que faz falecer nas pessoas a necessária motivação para uma participação ativa na vida política local, conforme excerto que garante o desfecho da plenária:

\begin{abstract}
"Não havendo mais questionamentos, a audiência Pública cumpriu seu papel e a seguinte ata foi lavrada por mim, Erickson Lima Ribeiro, e assinada pelos presentes que assim desejarem. João Pessoa quartorze de novembro de dois mil e dezessete".
\end{abstract}

Desta forma, é de se considerar que os procedimentos metodológicos precisam ser revisados, sob pena de relegar essa importante ferramenta de intervenção popular ao ostracismo e à insensibilidade do órgão ambiental.

Tal problemática corrobora com as críticas tecidas por Zhouri et al. 
(2008), que relatam múltiplas falhas processuais e materiais no processamento do EIA/RIMA, com a falta de divulgação, dificuldade de acesso, poucos esclarecimentos e debate frágil.

É de se registrar que a realização das audiências públicas não possui eficácia vinculatória absoluta, sendo certo que as decisões alcançadas no momento da reunião não possuem caráter decisório, o que aflora a precariedade e fragilidade dessa prática, que apesar de possuir fundamento nos relevantes anseios democráticos, suas decisões são incapazes de vincular a vontade da população sobre a concessão ou não de determinada licença ambiental para o funcionamento de um dado empreendimento.

\section{Considerações finais}

0 presente artigo debruçou-se sobre a participação popular no licenciamento ambiental, através da sua modalidade de manifestação, que se dá por meio de audiência pública, elencando-se sua importância e os obstáculos necessários à sua implementação.

A audiência pública, evidenciada pela participação popular, constitui etapa do procedimento de licenciamento ambiental, capaz de legitimar o feito administrativo, proporcionando um debate junto à população que será afetada pelo pretenso empreendimento, na esperança de fazer com que o Poder Público adote a melhor decisão, além de oportunizar a manifestação das minorias no diálogo sobre contundente questão ambiental, transformando-se numa verdadeira ferramenta de empoderamento popular. Entretanto, as audiências públicas acabam por se transformar em etapa administrativa para mero cumprimento do dever formal, de modo que a população além de não ser "ouvida", não usufrui, efetivamente, do modelo de crescimento e desenvolvimento prometido pelo empreendimento.

Diante da importância que as audiências públicas representam para o licenciamento ambiental, a intervenção popular deve ser preservada e potencializada, para oferecer um debate sistematicamente mais amplo, e com isso, exigir meios de crescimento e viabilidade socioambiental quando da aprovação ou não de determinado empreendimento.

É imperioso afirmar que uma discussão aberta e consciente no decurso da audiência pública, favorece um diálogo democrático no procedimento de licenciamento ambiental, o que viabiliza uma importante contribuição para que o Poder Público possa motivar a sua decisão pela concessão ou não da licença ambiental, que não só atenderá aos interesses particulares, mas, sobretudo aos interesses e ímpetos sociais, na medida em que a população tem a oportunidade de esclarecer possíveis dúvidas que pairam sobre os múltiplos impactos que determinado empreendimento poderá produzir em certa localidade, de modo que a própria população poderá formular sugestões e soluções acerca do projeto de instalação e funcionamento do projeto a ser implementado, sendo certo que caso a proposta não seja condizente com os ditames da legislação ambiental e o interesse público, a empresa que pleiteia o licenciamento, deverá necessariamente promover as mudanças necessárias à adequação do seu projeto.

No entanto, a probabilidade do insucesso das audiências públicas quanto à possibilidade de envidar contribuições efetivas para a preservação do meio ambiente é gritante, com vistas aos problemas detectados no presente estudo, pela falta de conscientização da população e na fase procedimental em que a audiência pública é realizada. 0 grande problema é que essas audiências, notadamente permeada de características que as fragilizam, conferem legitimidade ao procedimento licenciatório, o que muitas vezes torna a participação popular como mera etapa burocrática.

No caso concreto, evidencia-se que os instrumentos convocatórios, 
capazes de atrair a população para participar das audiências públicas, se mostra como meio infrutífero, na medida em que a população não acode ao convite formulado pela autoridade ambiental, através de editais colacionados no Diário Oficial do Estado e em jornais de grande circulação, cujo alcance populacional é muito diminuto, uma vez que a população, após a era digital, não mais consome informações por meio desses canais de comunicação. Dessa forma, a falta de divulgação cria um verdadeiro óbice para o pleno exercício de cidadania nessas audiências públicas, de modo que a veiculação em meios de comunicação impresso, notadamente jornais e diários oficiais, não são capazes de acudir quantitativo suficiente ao estabelecimento de debates arrazoados e enriquecedores para o licenciamento ambiental.

Neste pórtico, insta suscitar que a falta do acesso e uso da informação é motivo preponderante para manter os cidadãos alheios a tema tão caro e sensível à sociedade. As questões ambientais possuem $\mathrm{o}$ condão de interferir diretamente na vida das pessoas, de sorte que os temas oriundos dessas discussões, devem ser levados a amplo conhecimento da população, para que ela venha e possa intervir no processo decisório. Das convocatórias exprimidas pela SUDEMA, verifica-se que elas se valem de meios de comunicação obsoleto (jornais impressos), na medida em que a era da informação encontra-se objurgada por mídias digitais que concentram em si a atenção e o acesso imediato à informação.

Com efeito, é preciso investir mais na divulgação das audiências públicas, através de instrumentos notadamente utilizados pela população: redes sociais, propagandas radiofônicas/televisivas, jornais de grande circulação e etc., contendo informações básicas sobre o empreendimento e os impactos positivos/negativos a serem carreados por tal intento.
Indubitavelmente, é necessário garantir que essas audiências públicas ocorram em locais de fácil acessibilidade, para favorecer a todos os entes envolvidos, a fim de assegurar a máxima participação da população local envolvida, como forma de combater o fenômeno da acracia política.

Por outro lado, percebe-se que o EIA/RIMA não é disponibilizado, adequadamente, em favor da comunidade local. Foi possível observar que a população que atende ao chamado dos debates, insere-se nas discussões de forma rasa e superficial, em virtude de não ter sido previamente colocada a par dos detalhes dos estudos ambientais. Isso não edifica o debate, na medida em que o debate será travado de forma muito aquém ao que se poderia envidar, assim, a falta de conhecimento prévio às discussões favorece a apatia política.

Neste sentido, é preciso aplainar mais o conhecimento acerca da pretensa instalação de determinados projetos que produzam vultosos impactos ambientais, para trazer à lume mecanismos de mitigação e arrefecimento dos danos decorrentes de tal intento. Investir em mecanismos que promovam o necessário conhecimento dos efeitos da instalação de dado empreendimento, é assegurar um debate rico e elucidativo, capaz de produzir a contento os fins a que se destinam a audiência pública.

Diversos questionamentos que foram suscitados, não foram satisfatoriamente respondidos, e algumas vezes, houve comprometimento de alteração dos projetos, em absorção à sugestão posta em audiência. Porém, nesses casos, não se verificou a efetiva alteração do projeto, tampouco tal exigibilidade por parte da autoridade ambiental.

A população não é consultada sobre a viabilidade ou não acerca do deferimento do licenciamento ambiental, sua opinião é ignorada pela autoridade ambiental, que sequer põe em votação a opinião dos cidadãos ali presentes.

Portanto, dentro da acepção de uma decisão política, embasada na 
necessidade de se conferir uma gestão participativa de empoderamento popular, é preciso garantir à população a competência para decidir sobre a (in)viabilidade de determinado empreendimento local, sem prejuízo ao interesse público, que deverá restar necessáriamente fundamentado, sempre que a viabilidade do empreendimento reste questionada em decisão popular.

Por último, é preciso dar espaço e garantias às decisões tomadas pela população local. Um Estado Democrático, calcado na soberania das decisões populares, precisa respeitar as decisões dos seus cidadãos. As audiências públicas atualmente servem apenas para se realizar uma prestação satisfativa à sociedade, sem levar a cabo os interesses dos indivíduos envolvidos.

Neste sentido, insta reclamar por uma reflexão aprofundada e acurada sobre a necessidade de ser realizar uma ávida e proveitosa intervenção popular no licenciamento ambiental, como forma de superar os problemas nucleares que obstam a articulação e o pleno desenvolvimento dessa importante ferramenta da democracia participativa, através de um trabalho de educação ambiental, para fomentar nas pessoas, provenientes de todos os níveis socioeconômicos, um senso crítico sobre os aspectos ambientais, bem como a necessidade de proteger e preservar o meio ambiente, além de se promover uma reforma urgente da legislação ambiental, com o fito de solver o problema do momento em que a audiência pública ocorre no procedimento licenciatório, uma vez que a intervenção popular ocorre numa fase processual muito avançada do licenciamento ambiental, já que nessa ocasião vultosas somas pecuniárias já foram desprendidas em projetos e estudos, de sorte que a população local já está cerceada da ideia progressista, irreversível e irretratável da pretensa instalação e operação de determinado empreendimento.
Por essa razão, é imperioso trazer à baila os princípios decorrentes da democracia participativa inseridos nas audiências públicas, como forma de inibir que essa importante ferramenta democrática se torne para os empreendimentos apenas mais uma característica formal e burocrática para o alcance da pretensa licença ambiental, na medida em que a audiência pública é um mecanismo de empoderamento popular, do qual decorrem da legalidade - eis que se trata de requisito extrínseco do procedimento -, e confere legitimidade ao licenciamento ambiental, sob a valorosa premissa do Estado Democrático de intervenção das massas populacionais afetadas pelas decisões políticas, que permite o desenvolvimento da democracia participativa e assegura a necessária proteção socioambiental, que garantirá a prevalência do direito ao meio ambiente ecologicamente equilibrado, para as presentes e futuras gerações, na forma que é tutelada pela Constituição Federal de 1988 (Brasil, 1988).

\section{Conflitos de interesse}

Os autores declaram não haver conflitos de interesse.

\section{Referências}

Agra Filho, S. S. Conflitos ambientais e os instrumentos da Política Nacional de Meio Ambiente. eGesta - Revista Eletrônica de Gestão de Negócios, v. 4, n. 2, p. 127-140, 2008. Disponível em: <https://www. unisantos.br/mestrado/gestao/egesta/artigo s/149.pdf>. Acesso em: 06 jun. 2018.

Agra Filho, S. S. Conflitos ambientais e os instrumentos da Política Nacional de Meio Ambiente: Desenvolvimento e conflitos ambientais. Belo Horizonte: UFMG, 2010.

Almeida, A. N.; Kanieski, M. R.; Soares, P. R. C.; Angelo, H. Principais problemas na previsão e avaliação de impactos ambientais nos Estudos de Impacto Ambiental (EIAs): uma aplicação da análise de correlação canônica. Revista Brasileira de Gestão Ambiental e 
Sustentabilidade, v. 4, n. 7, p. 31-42, 2017. https://doi.org/10.21438/rbgas.040704

Almeida, A. N.; Rodrigues, N. G.; Vieira, L. C. G.; Couto Junior, A. F. Problemas nos estudos de impacto ambiental de rodovias e ferrovias. Revista Brasileira de Gestão Ambiental e Sustentabilidade, v. 6 , n. 12 , p. 129-136, 2019 . https://doi.org/10.21438/rbgas. 061210

Amado, F. Direito ambiental. 3. ed. São Paulo: Método, 2015.

Antunes, P. B. Direito ambiental. 14. ed. São Paulo: Atlas, 2012.

Assunção, F. N. A.; Bursztyn, M. A. A.; Abreu, T. L. M. Participação social na avaliação de impacto ambiental: lições da experiência da Bahia. Confins. Revista Franco-Brasilera de Geografia, v. 10, 2010. https://doi.org/ 10.4000/confins. 6750

Assunção, L. O. A participação popular nas audiências públicas para licenciamento. Revista Científica do Curso de Direito do CEAP, v. 1, p. 1-9, 2011.

Ayres Britto, C. Distinção entre controle social do poder e participação popular. Revista de Direito Administrativo, n. 189, p. 114-122, 1992. https://doi.org/10.12660/ rda.v189.1992.45286

Baptista, B.G. L. Oralidade no direito administrativo: licenciamento ambiental e audiência pública. 2007. Disponível em: <http://www.mundojuridico.adv.br>. Acesso em: 06 jun. 2018.

Bercovici, G. Constituição econômica e desenvolvimento: uma leitura a partir da Constituição de 1988. São Paulo: Malheiros, 2005.

Bim, E. F. Licenciamento ambiental. 3. ed. Rio de Janeiro: Lumen Juris, 2016.

Bobbio, N. O futuro da democracia. São Paulo: Paz e Terra, 2011.

Brasil. Constituição da República Federativa do Brasil de 1988. Disponível em: <http://www.planalto.gov.br/ccivil_03/ constituicao/constituicao.htm>. Acesso em: 06 jun. 2018.

Brasil. Lei Complementar no 140, de 08 de dezembro de 2011. Fixa normas, nos termos dos incisos III, VI e VII do caput e do parágrafo único do art. 23 da Constituição Federal, para a cooperação entre a União, os
Estados, o Distrito Federal e os Municípios nas ações administrativas decorrentes do exercício da competência comum relativas à proteção das paisagens naturais notáveis, à proteção do meio ambiente, ao combate à poluição em qualquer de suas formas e à preservação das florestas, da fauna e da flora; e altera a Lei ${ }^{\circ}$ 6.938, de 31 de agosto de 1981. Disponível em: <http://www.planalto. gov.br/ccivil_03/leis/lcp/lcp140.htm>.

Acesso em: 06 jun. 2018.

Brasil. Decreto no 99.274, de 06 de junho de 1990. Regulamenta a Lei no 6.902 , de 27 de abril de 1981, e a Lei no 6.938, de 31 de agosto de 1981, que dispõem, respectivamente sobre a criação de Estações Ecológicas e Áreas de Proteção Ambiental e sobre a Política Nacional do Meio Ambiente, e dá outras providências. Disponível em: <http://www.planalto.gov.br/ccivil_03/decr eto/Antigos/D99274.htm>. Acesso em: 06 jun. 2018.

Brasil. Lei no 4.717, de 29 de junho de 1965. Regula a ação popular. Disponível em: <http://www.planalto.gov.br/ccivil_03/leis/l 4717.htm>. Acesso em: 06 jun. 2018.

Brasil. Lei no 6.938, de 31 de agosto de 1981. Dispõe sobre a Política Nacional do Meio Ambiente, seus fins e mecanismos de formulação e aplicação, e dá outras providências. Disponível em: <http://www. planalto.gov.br/ccivil_03/leis/L6938compila da.htm>. Acesso em: 06 jun. 2018.

Brasil. Resolução CONAMA no 001, de 23 de janeiro de 1986. Disponível em: <http://www2.mma.gov.br/port/conama/re s/res86/res0186.html>. Acesso em: 06 jun. 2018.

Brasil. Resolução CONAMA no 09, de 3 de dezembro de 1987. Dispõe sobre a realização de Audiências Públicas no processo de licenciamento ambiental. Disponível em: <http://www2.mma.gov.br/ port/conama/legiabre.cfm?codlegi=60>.

Acesso em: 06 jun. 2018.

Brasil. Resolução CONAMA no 237, de 19 de dezembro de 1997. Disponível em: <http://www2.mma.gov.br/port/conama/re s/res97/res23797.html $>$. Acesso em: 06 jun. 2018.

Borges, L. A. C.; Rezende, J. L. P.; Coelho Júnior, L. M. Áreas de proteção ambiental no interior de propriedades rurais - APP e RL. 
Anais do Congresso Internacional de Direito Ambiental, 2009. São Paulo: Imprensa Oficial do Estado de São Paulo, 2009. v. 2. p. 397412.

César, J. B. M. A audiência pública como instrumento de efetivação dos direitos sociais. Revista Mestrado em Direito, v. 5, n. 2, p. 356-384, 2011.

Derani, C. Direito ambiental econômico. 2. ed. São Paulo: Max Limonad, 2001.

Dias, E. C. Manual de direito ambiental. Belo Horizonte: Mandamentos, 2003.

Farias, T. Licenciamento ambiental: aspectos teóricos e práticos. 6. ed. Belo Horizonte: Fórum, 2017.

Farias, T.; Coutinho, F. S. N.; Melo, G. K. R. R. Direito ambiental. 2. ed. Belo Horizonte: Jus Podium, 2015.

Guerra, S.; Guerra, S. Intervenção estatal ambiental: licenciamento e compensação de acordo com a Lei Complementar $\mathrm{n}$ 은 140/2011. São Paulo: Atlas, 2012.

Habermas, J. Direito e democracia: entre facticidade e validade. Rio de Janeiro: Tempo Brasileiro, 1997. v. 2.

IBGE - Instituto Brasileiro de Geografia e Estatística. Conheça cidades e estados do Brasil. 2018. Disponível em: <https://cidades.ibge.gov.br/brasil/pb/pano rama>. Acesso em: 10 jul. 2018.

Machado, P.A. L. Direito ambiental brasileiro. 12. ed. São Paulo: Malheiros, 2004.

Madruga Filho, V. J. P.; Fernandes, H. F.; Silva, J. R. S. Direito internacional ambiental e sua interface no contexto constitucional brasileiro. Revista Brasileira de Educação Ambiental e Sustentabilidade, v. 5, n. 10, p. 517-526, 2018. https://doi.org/10.21438/ rbgas. 051007

Magalhães, J. L. Q. 0 resgate da democracia representativa através da democracia participativa. Revista da Faculdade de Direito da Universidade Federal de Minas Gerais, v. 44, p. 183-216, 1999.

Milaré, E. Direito do ambiente. São Paulo: RT, 2000.

Milaré, E. Direito do ambiente: doutrina, jurisprudência, glossário. 4. ed. São Paulo: RT, 2005.
Miranda, C. G. S. A participação popular como instrumento de legitimidade do procedimento de licenciamento ambiental. Âmbito Jurídico, v. 16, n. 115, 2013. Disponível em: <http://www.ambitojuridico. com.br/site/index.php?n_link=revista_artigo s_leitura\&artigo_id=13145>. Acesso em: 20 jul. 2018.

Mirra, A. L. V. Impacto ambiental: aspectos da legislação brasileira. São Paulo: Oliveira Mendes, 1998.

Modesto, P. Participação popular na administração pública: mecanismos de operacionalização. 2006. Disponível em: <http://egov.ufsc.br/portal/sites/default/fil es/anexos/19909-19910-1-PB.pdf>. Acesso em: 11 jun. 2018.

Moreira Neto, D. F. Mutações do Direito Administrativo. 2. ed. Rio de Janeiro: Renovar, 2001.

Neves, H. T. Precariedade e revisão da licença ambiental. Revista Brasileira de Gestão Ambiental e Sustentabilidade, v. 1, n. 1, p. 35-47, 2014. https://doi.org/10.21438/ rbgas.010105

Paraíba. Lei no 4.033, de 20 de dezembro de 1978. Dispõe sobre a criação da Superintendência de Administração do MeioAmbiente e dos Recursos Hídricos da Paraíba-SUDEMA/PB e dá outras providências. Disponível em: <http://sapl.al.pb.leg.br/sapl/sapl_document os/norma_juridica/3505_texto_integral>. Acesso em: 11 jul. 2018.

Paraíba. Lei Complementar no 59, de 30 de dezembro de 2003. Cria a Região Metropolitana de João Pessoa, o Fundo de Desenvolvimento Metropolitano e dá outras providências. Disponível em: <http://sapl.al.pb.leg.br/sapl/sapl_document os/norma_juridica/5579_texto_integral >.

Acesso em: 11 jul. 2018.

Paraíba. Lei Complementar no 90, de 23 de setembro de 2009. Dá nova redação ao art. 1ํo, do Capítulo I, da Lei Complementar no 59 , de 30 de dezembro de 2003, e dá outras providências. Disponível em: <http://sapl.al.pb.leg.br/sapl/sapl_document os/norma_juridica/9379_texto_integral>. Acesso em: 11 jul. 2018.

Paraíba. Lei Complementar no 93, de 11 de dezembro de 2009. Dá nova redação ao art. $1^{\circ}$ da Lei Complementar $\mathrm{n}^{\circ}$ 59, de 30 de 
dezembro de 2003, e dá outras providências.

Disponível em: <http://sapl.al.pb.leg.br/ sapl/sapl_documentos/norma_juridica/9427 _texto_integral>. Acesso em: 11 jul. 2018.

Paraíba. Portaria SUDEMA DS no 071, de 27 de maio de 2011. Disponível em: $<$ https://auniao.pb.gov.br/servicos/arquivodigital/doe/2011/maio/diario-oficial-29-052011.pdf\#page=5>. Acesso em: 11 jul. 2018 .

Reigota, M. 0 que é educação ambiental. 2. ed. São Pulo: Brasiliense, 2009.

Siqueira, L. C. Política ambiental para quem? Ambiente \& Sociedade, v. 11 , n. 2, p. 425437, 2008. https://doi.org/10.1590/S1414753X2008000200014

Zhouri, A.; Laschefski, K.; Paiva, A. Uma sociologia do licenciamento ambiental: o caso das hidrelétricas em Minas Gerais. In: Zhouri, A.; Laschefski, K.; Pereira, D. (Orgs.). A insustentável leveza da política ambiental: desenvolvimento e conflitos socioambientais. Belo Horizonte: Autêntica, 2005. 